4

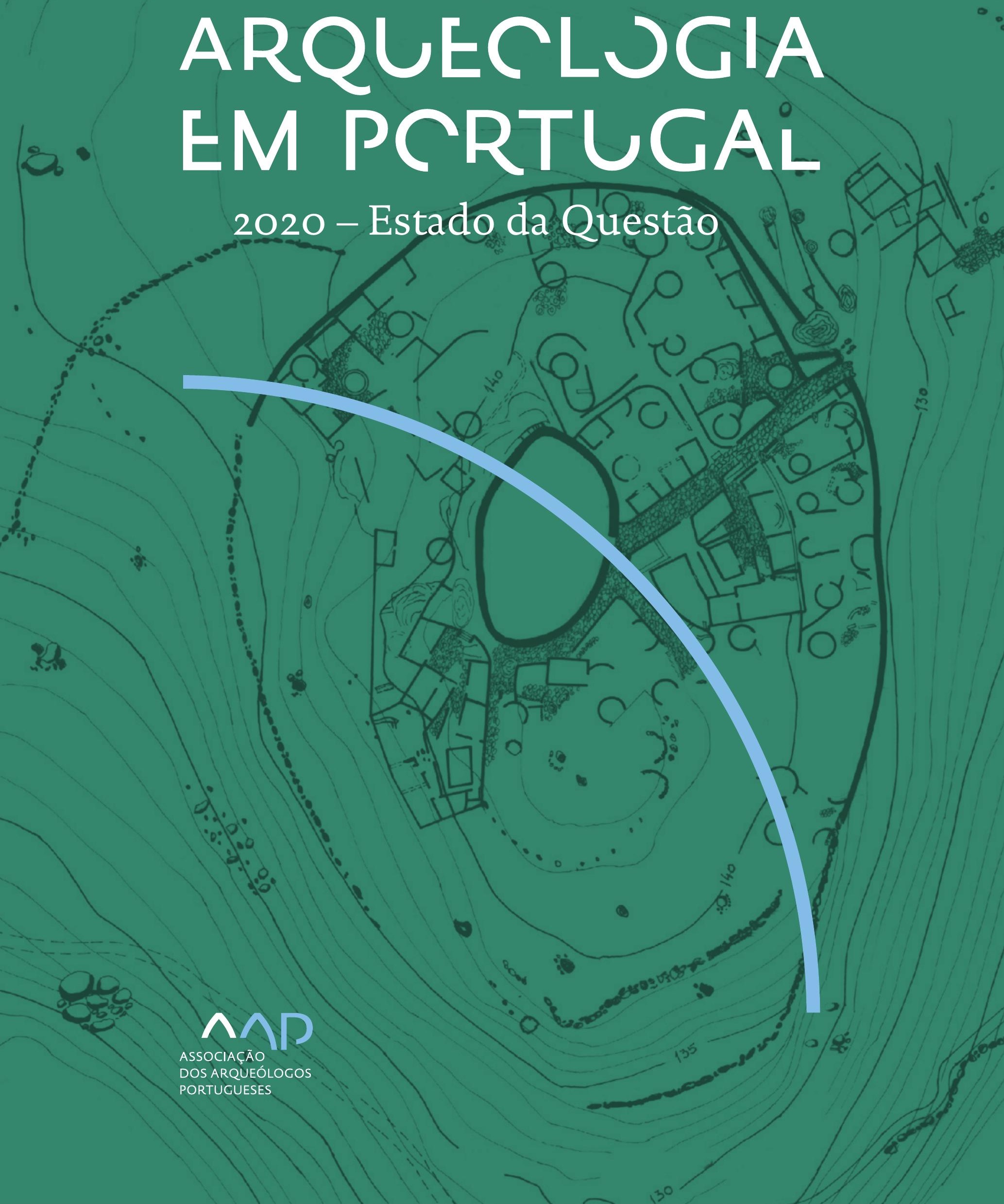


Coordenação editorial: José Morais Arnaud, César Neves e Andrea Martins Design gráfico: Flatland Design

AAP - ISBN: 978-972-9451-89-8

CITCEM - ISBN: 978-989-8970-25-1

Associação dos Arqueólogos Portugueses e CITCEM

Lisboa, 2020

O conteúdo dos artigos é da inteira responsabilidade dos autores. Sendo assim a Associação dos Arqueólogos Portugueses declina qualquer responsabilidade por eventuais equívocos ou questões de ordem ética e legal.

Desenho de capa:

Planta do castro de Monte Mozinho (Museu Municipal de Penafiel).

\section{$\hat{\wedge} \mathrm{P}$}

DOS ARQUEÓLOGOS PORTUGUESES

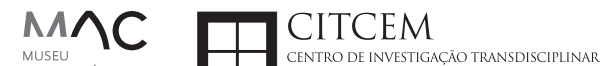
MUSEU
ARQUELLÓGICO
DO CARMO
U.PORTO

FLUP FACULDADE DE LETRAS
UNIVERSIDADE DO PORTO

Apoio

EC para a Ciência 


\section{Índice}

15 Prefácio

José Morais Arnaud

\section{Historiografia e Teoria}

17 Território, comunidade, memória e emoção: a contribuição da história da arqueologia (algumas primeiras e breves reflexões)

Ana Cristina Martins

25 Como descolonizar a arqueologia portuguesa?

Rui Gomes Coelho

41 Arqueologia e Modernidade: uma revisitação pessoal e breve de alguns aspetos da obra homónima de Julian Thomas de 2004

Vítor Oliveira Jorge

57 Dados para a História das Mulheres na Arqueologia portuguesa, dos finais do século XIX aos inícios do século XX: números, nomes e tabelas

Filipa Dimas / Mariana Diniz

73 Retractos da arqueologia portuguesa na imprensa: (in)visibilidades no feminino

Catarina Costeira / Elsa Luís

85 Arqueologia e Arqueólogos no Norte de Portugal Jacinta Bugalhão

101 Vieira Guimarães (1864-1939) e a arqueologia em Tomar: uma abordagem sobre o território e as gentes

João Amendoeira Peixoto / Ana Cristina Martins

115 Os memoráveis? A arqueologia algarvia na imprensa nacional e regional na presente centúria (2001-2019): características, visões do(s) passado(s) e a arqueologia

enquanto marca

Frederico Agosto / João Silva

129 A Evolução da Arqueologia Urbana e a Valorização Patrimonial no Barlavento Algarvio: Os casos de Portimão e Silves

Artur Mateus / Diogo Varandas / Rafael Boavida

\section{Gestão, Valorização e Salvaguarda do Património}

145 O Caderno Reivindicativo e as condições de trabalho em Arqueologia Miguel Rocha / Liliana Matias Carvalho / Regis Barbosa / Mauro Correia / Sara Simões / Jacinta Bugalhão / Sara Brito / Liliana Veríssimo Carvalho / Richard Peace / Pedro Peça / Cézer Santos

155 Os Estudos de Impacte Patrimonial como elemento para uma estratégia sustentável de minimização de impactes no âmbito de reconversões agrícolas Tiago do Pereiro

165 Salvaguarda de Património arqueológico em operações florestais: gestão e sensibilização Filipa Bragança / Gertrudes Zambujo / Sandra Lourenço / Belém Paiva / Carlos Banha / Frederico Tatá Regala / Helena Moura / Jacinta Bugalhão / João Marques / José Correia / Pedro Faria / Samuel Melro

179 Os valores do Património: uma investigação sobre os Sítios Pré-históricos de Arte Rupestre do Vale do Rio Côa e de Siega Verde José Paulo Francisco 
189 Conjugando recursos arqueológicos e naturais para potenciar as visitas ao Geoparque Litoral de Viana do Castelo (Noroeste de Portugal)

Hugo A. Sampaio / Ana M.S. Bettencourt / Susana Marinho / Ricardo Carvalhido

203 Áreas de Potencial Arqueológico na Região do Médio Tejo: Modelo Espacial Preditivo Rita Ferreira Anastácio / Ana Filipa Martins / Luiz Oosterbeek

223 Património Arqueológico e Gestão Territorial: O contributo da Arqueologia para a revisão do PDM de Avis

Ana Cristina Ribeiro

237 A coleção arqueológica do extinto Museu Municipal do Porto - Origens, Percursos e Estudos

Sónia Couto

251 Valpaços - uma nova carta arqueológica

Pedro Pereira / Maria de Fátima Casares Machado

263 Arqueologia na Cidade de Peniche

Adriano Constantino / Luís Rendeiro

273 Arqueologia Urbana: a cidade de Lagos como caso de Estudo Cátia Neto

285 Estratégias de promoção do património cultural subaquático nos Açores. O caso da ilha do Faial

José Luís Neto / José Bettencourt / Luís Borges / Pedro Parreira

297 Carta Arqueológica da Cidade Velha: Uma primeira abordagem

Jaylson Monteiro / Nireide Tavares / Sara da Veiga / Claudino Ramos / Edson Brito /

Carlos Carvalho / Francisco Moreira / Adalberto Tavares

311 Antropologia Virtual: novas metodologias para a análise morfológica e funcional Ricardo Miguel Godinho / Célia Gonçalves

\section{Didáctica da Arqueologia}

327 Como os projetos de Arqueologia podem contribuir para uma comunidade culturalmente mais consciente Alexandra Figueiredo / Claúdio Monteiro / Adolfo Silveira / Ricardo Lopes

337 Educação Patrimonial - Um cidadão esclarecido é um cidadão ativo! Ana Paula Almeida

351 A aproximação da Arqueologia à sala de aula: um caso de estudo no $3^{\circ}$ ciclo do Ensino Básico Luís Serrão Gil

363 Arqueologia 3.o - Pensar e comunicar a Arqueologia para um futuro sustentável Mónica Rolo

377 “Conversa de Arqueólogos" - Divulgar a Arqueologia em tempos de Pandemia Diogo Teixeira Dias

389 Escola Profissional de Arqueologia: desafios e oportunidades Susana Nunes / Dulcineia Pinto / Júlia Silva / Ana Mascarenhas

399 Os Museus de Arqueologia e os Jovens: a oferta educativa para o público adolescente Beatriz Correia Barata / Leonor Medeiros

411 O museu universitário como mediador entre a ciência e a sociedade: o exemplo da secção de arqueologia no Museu de História Natural e da Ciência da Universidade do Porto (MHNC-UP)

Rita Gaspar 
421 Museu de Lanifícios: Real Fábrica de Panos. Atividades no âmbito da Arqueologia Beatriz Correia Barata / Rita Salvado

427 Arqueologia Pública e o caso da localidade da Mata (Torres Novas) Cláudia Manso / Ana Rita Ferreira / Cristiana Ferreira / Vanessa Cardoso Antunes

431 Do sítio arqueológico ao museu: um percurso (também) didático Lídia Fernandes

447 Estão todos convidados para a Festa! E para dançar também... O projecto do Serviço Educativo do Museu Arqueológico do Carmo na $5^{\underline{a}}$ Edição da Festa da Arqueologia Rita Pires dos Santos

459 O “Clã de Carenque”, um projeto didático de arqueologia Eduardo Gonzalez Rocha

469 Mediação cultural: peixe que puxa carroça nas Ruínas Romanas de Troia Inês Vaz Pinto / Ana Patrícia Magalhães / Patrícia Brum / Filipa Santos

481 Didática Arqueológica, experiências do Projeto Mértola Vila Museu Maria de Fátima Palma / Clara Rodrigues / Susana Gómez / Lígia Rafael

\section{Arte Rupestre}

497 Os inventários de arte rupestre em Portugal Mila Simões de Abreu

513 O projeto FIRST-ART - conservação, documentação e gestão das primeiras manifestações de arte rupestre no Sudoeste da Península Ibérica: as grutas do Escoural e Maltravieso Sara Garcês / Hipólito Collado / José Julio García Arranz / Luiz Oosterbeek / António Carlos Silva / Pierluigi Rosina / Hugo Gomes / Anabela Borralheiro Pereira / George Nash / Esmeralda Gomes / Nelson Almeida / Carlos Carpetudo

523 Trabalhos de documentação de arte paleolítica realizados no âmbito do projeto PalæoCôa André Tomás Santos / António Fernando Barbosa / Luís Luís / Marcelo Silvestre / Thierry Aubry

537 Imagens fantasmagóricas, silhuetas elusivas: as figuras humanas na arte do Paleolítico Superior da região do Côa Mário Reis

$55^{1}$ Os motivos zoomórficos representados nas placas de tear de Vila Nova de São Pedro (Azambuja, Portugal) Andrea Martins / César Neves / José M. Arnaud / Mariana Diniz

571 Arte Rupestre do Monte de Góios (Lanhelas, Caminha). Síntese dos resultados dos trabalhos efectuados em 2007-2009 Mário Varela Gomes

599 Gravuras rupestres de barquiformes no Monte de S. Romão, Guimarães, Noroeste de Portugal Daniela Cardoso

613 Círculos segmentados gravados na Bacia do Rio Lima (Noroeste de Portugal): contributos para o seu estudo Diogo Marinho / Ana M.S. Bettencourt / Hugo Aluai Sampaio

631 Equídeos gravados no curso inferior do Rio Mouro, Monção (NW Portugal). Análise preliminar Coutinho, L.M. / Bettencourt, A.M.S / Sampaio, Hugo A.S

645 Paletas na Arte Rupestre do Noroeste de Portugal. Inventário preliminar Bruna Sousa Afonso / Ana M. S. Bettencourt / Hugo A. Sampaio 


\section{Pré-História}

661 O projeto Miño/Minho: balanço de quatro anos de trabalhos arqueológicos Sérgio Monteiro-Rodrigues / João Pedro Cunha-Ribeiro / Eduardo Méndez-Quintas / Carlos Ferreira / Pedro Xavier / José Meireles / Alberto Gomes / Manuel Santonja / Alfredo Pérez-González

677 A ocupação paleolítica da margem esquerda do Baixo Minho: a indústria lítica do sítio de Pedreiras 2 (Monção, Portugal) e a sua integração no contexto regional Carlos Ferreira / João Pedro Cunha-Ribeiro / Sérgio Monteiro-Rodrigues / Eduardo Méndez-Quintas / Pedro Xavier / José Meireles / Alberto Gomes / Manuel Santonja / Alfredo Pérez-González

693 O sítio acheulense do Plistocénico médio da Gruta da Aroeira Joan Daura / Montserrat Sanz / Filipa Rodrigues / Pedro Souto / João Zilhão

703 As sociedades neandertais no Barlavento algarvio: modelos preditivos com recurso aos SIG

Daniela Maio

715 A utilização de quartzo durante o Paleolítico Superior no território dos vales dos rios Vouga e Côa

Cristina Gameiro / Thierry Aubry / Bárbara Costa / Sérgio Gomes / Luís Luís / Carmen Manzano / André Tomás Santos

733 Uma perspetiva diacrónica da ocupação do concheiro do Cabeço da Amoreira (Muge, Portugal) a partir da tecnologia lítica Joana Belmiro / João Cascalheira / Célia Gonçalves

745 Novos dados sobre a Pré-história Antiga no concelho de Palmela. A intervenção arqueológica no sítio do Poceirão I

Michelle Teixeira Santos

757 Problemas em torno de Datas Absolutas Pré-Históricas no Norte do Alentejo Jorge de Oliveira

771 Povoamento pré-histórico nas áreas montanhosas do NO de Portugal: o Abrigo 1 de Vale de Cerdeira Pedro Xavier / José Meireles / Carlos Alves

783 Apreciação do povoamento do Neolítico Inicial na Baixa Bacia do Douro. A Lavra I (Serra da Aboboreira) como caso de estudo Maria de Jesus Sanches

797 O Processo de Neolitização na Plataforma do Mondego: os dados do Sector C do Outeiro dos Castelos de Beijós (Carregal do Sal)

João Carlos de Senna-Martinez / José Manuel Quintã Ventura / Andreia Carvalho / Cíntia Maurício

823 Novos trabalhos na Lapa da Bugalheira (Almonda, Torres Novas) Filipa Rodrigues / Pedro Souto / Artur Ferreira / Alexandre Varanda / Luís Gomes / Helena Gomes / João Zilhão

837 A pedra polida e afeiçoada do sítio do Neolítico médio da Moita do Ourives (Benavente, Portugal)

César Neves

857 Casal do Outeiro (Encarnação, Mafra): novos contributos para o conhecimento do povoamento do Neolítico final na Península de Lisboa.

Cátia Delicado / Carlos Maneira e Costa / Marta Miranda / Ana Catarina Sousa

873 Stresse infantil, morbilidade e mortalidade no sítio arqueológico do Neolítico Final/ Calcolítico ( $4^{\circ}$ e $3^{\circ}$ milénio a.C.) do Monte do Carrascal 2 (Ferreira do Alentejo, Beja) Liliana Matias de Carvalho / Sofia N. Wasterlain 
885 Come together: O Conjunto Megalítico das Motas (Monção, Viana do Castelo) e as expressões Campaniformes do Alto Minho Ana Catarina Basílio / Rui Ramos

899 Trabalhos arqueológicos no sítio Calcolítico da Pedreira do Poio Carla Magalhães / João Muralha / Mário Reis / António Batarda Fernandes

913 O sítio arqueológico de Castanheiro do Vento. Da arquitectura do sítio à arquitectura de um território João Muralha Cardoso

925 Estudo zooarqueológico das faunas do Calcolítico final de Vila Nova de São Pedro (Azambuja, Portugal): Campanhas de 2017 e 2018 Cleia Detry / Ana Catarina Francisco / Mariana Diniz / Andrea Martins / César Neves / José Morais Arnaud

943 As faunas depositadas no Museu Arqueológico do Carmo provenientes de Vila Nova de São Pedro (Azambuja): as campanhas de 1937 a 1967 Ana Catarina Francisco / Cleia Detry / César Neves / Andrea Martins / Mariana Diniz / José Morais Arnaud

959 Análise funcional de material lítico em sílex do castro de Vila Nova de S. Pedro (Azambuja, Portugal): uma primeira abordagem Rafael Lima

971 O recinto da Folha do Ouro 1 (Serpa) no contexto dos recintos de fossos calcolíticos alentejanos

António Carlos Valera / Tiago do Pereiro / Pedro Valério / António M. Monge Soares

\section{Proto-História}

987 Produção de sal marinho na Idade do Bronze do noroeste Português. Alguns dados para uma reflexão

Ana M. S. Bettencourt / Sara Luz / Nuno Oliveira / Pedro P. Simões / Maria Isabel C. Alves / Emílio Abad-Vidal

1001 A estátua-menir do Pedrão ou de São Bartolomeu do Mar (Esposende, noroeste de Portugal) no contexto arqueológico da fachada costeira de entre os rios Neiva e Cávado Ana M. S. Bettencourt / Manuel Santos-Estévez / Pedro Pimenta Simões / Luís Gonçalves

1015 O Castro do Muro (Vandoma/Baltar, Paredes) - notas para uma biografia de ocupação da Idade do Bronze à Idade Média

Maria Antónia D. Silva / Ana M. S. Bettencourt / António Manuel S. P. Silva / Natália Félix

1031 Do Bronze Final à Idade Média - continuidades e hiatos na ocupação de Povoados em Oliveira de Azeméis João Tiago Tavares / Adriaan de Man

1041 As faunas do final da Idade do Bronze no Sul de Portugal: leituras desde o Outeiro do Circo (Beja)

Nelson J. Almeida / Íris Dias / Cleia Detry / Eduardo Porfírio / Miguel Serra

1055 A Espada do Monte das Oliveiras (Serpa) - uma arma do Bronze Pleno do Sudoeste Rui M. G. Monge Soares / Pedro Valério / Mariana Nabais / António M. Monge Soares

1065 São Julião da Branca (Albergaria-a-Velha) - Investigação e valorização de um povoado do Bronze Final

António Manuel S. P. Silva / Paulo A. P. Lemos / Sara Almeida e Silva / Edite Martins de Sá

1083 Do castro de S. João ao Mosteiro de Santa Clara: notícia de uma intervenção arqueológica, em Vila do Conde Rui Pinheiro 
1095 O castro de Ovil (Espinho), um quarto de século de investigação - resultados e questões em aberto

Jorge Fernando Salvador / António Manuel S. P. Silva

1111 O Castro de Salreu (Estarreja), um povoado proto-histórico no litoral do Entre Douro e Vouga

Sara Almeida e Silva / António Manuel S. P. Silva / Paulo A. P. Lemos / Edite Martins de Sá

1127 Castro de Nossa Senhora das Necessidades (Sernancelhe): uma primeira análise artefactual Telma Susana O. Ribeiro

${ }_{1141}$ A cividade de Bagunte. O estado atual da investigação Pedro Brochado de Almeida

1153 Zoomorfos na cerâmica da Idade do Ferro no NW Peninsular: inventário, cronologias e significado Nuno Oliveira / Cristina Seoane

1163 Vasos gregos em Portugal: diferentes maneiras de contar a história do intercâmbio cultural na Idade do Ferro

Daniela Ferreira

1175 Os exotica da necrópole da Idade do Ferro do Olival do Senhor dos Mártires (Alcácer do Sal) no seu contexto regional

Francisco B. Gomes

\section{Antiguidade Clássica e Tardia}

1191 O uso de madeira como combustível no sítio da Quinta de Crestelos (Baixo Sabor): da Idade do Ferro à Romanização Filipe Vaz / João Tereso / Sérgio Simões Pereira / José Sastre / Javier Larrazabal Galarza / Susana Cosme / José António Pereira / Israel Espi

1207 Cultivos de Época Romana no Baixo Sabor: continuidade em tempos de mudança? João Pedro Tereso / Sérgio Simões Pereira / Filipe Santos / Luís Seabra / Filipe Vaz

1221 A casa romana na Hispânia: aplicação dos modelos itálicos nas províncias ibéricas Fernanda Magalhães / Diego Machado / Manuela Martins

1235 As pinturas murais romanas da Rua General Sousa Machado, n. ${ }^{5}$ 1, Chaves José Carvalho

1243 Trás do Castelo (Vale de Mir, Pegarinhos, Alijó) - Uma exploração agrícola romana do Douro

Tony Silvino / Pedro Pereira

1255 A sequência de ocupação no quadrante sudeste de Bracara Augusta: as transformações de uma unidade doméstica Lara Fernandes / Manuela Martins

1263 Os Mosaicos com decoração geométrica e geométrico-vegetalista dos sítios arqueológicos da área do Conuentus Bracaraugustanus. Novas abordagens quanto à conservação, restauro, decoração e datação Maria de Fátima Abraços / Licínia Wrench

1277 “Casa Romana” do Castro de São Domingos (Cristelos, Lousada): Escavação, Estudo e Musealização Paulo André de P. Lemos

1291 A arqueobotânica no Castro de Guifões (Matosinhos, Noroeste de Portugal): O primeiro estudo carpológico

Luís Seabra / Andreia Arezes / Catarina Magalhães / José Varela / João Pedro Tereso 
1305 Um Horreum Augustano na Foz do Douro (Monte do Castelo de Gaia, Vila Nova de Gaia) Rui Ramos

1311 Ponderais romanos na Lusitânia: padrões, formas, materiais e contextos de utilização Diego Barrios Rodríguez

1323 Um almofariz centro-itálico na foz do Mondego

Marco Penajoia

1335 Estruturas romanas de Carnide - Lisboa Luísa Batalha / Mário Monteiro / Guilherme Cardoso

1347 O contexto funerário do sector da "necrópole NO" da Rua das Portas de S. Antão (Lisboa): o espaço, os artefactos, os indivíduos e a sua interconectividade na interpretação do passado Sílvia Loja, José Carlos Quaresma, Nelson Cabaço, Marina Lourenço, Sílvia Casimiro, Rodrigo Banha da Silva, Francisca Alves-Cardoso

${ }_{1361}$ Povoamento em época Romana na Amadora - resultados de um projeto pluridisciplinar Gisela Encarnação / Vanessa Dias

1371 A Arquitectura Residencial em Mirobriga (Santiago do Cacém): contributo a partir de um estudo de caso Filipe Sousa / Catarina Felício

${ }_{1385}$ O fim do ciclo. Saneamento e gestão de resíduos nos edifícios termais de Mirobriga (Santiago do Cacém)

Catarina Felício / Filipe Sousa

1399 Balsa, Topografia e Urbanismo de uma Cidade Portuária Vítor Silva Dias / João Pedro Bernardes / Celso Candeias / Cristina Tété Garcia

1413 No Largo das Mouras Velhas em Faro (2017): novas evidências da necrópole norte de Ossonoba e da sua ocupação medieval Ricardo Costeira da Silva / Paulo Botelho / Fernando Santos / Liliana Nunes

1429 Instrumentos de pesca recuperados numa fábrica de salga em Ossonoba (Faro) Inês Rasteiro / Ricardo Costeira da Silva / Paulo Botelho

1439 A Necrópole Romana do Eirô, Duas Igrejas (Penafiel): intervenção arqueológica de 2016 Laura Sousa / Teresa Soeiro

1457 Ritual, descarte ou afetividade? A presença de Canis lupus familiaris na Necrópole Noroeste de Olisipo (Lisboa)

Beatriz Calapez Santos / Sofia Simões Pereira / Rodrigo Banha da Silva / Sílvia Casimiro / Cleia Detry / Francisca Alves Cardoso

1467 Dinâmicas económicas em Bracara na Antiguidade Tardia Diego Machado / Manuela Martins / Fernanda Magalhães / Natália Botica

1479 Cerâmicas e Vidros da Antiguidade Tardia do Edifício sob a Igreja do Bom Jesus (Vila Nova de Gaia) Joaquim Filipe Ramos

1493 Novos contributos para a topografia histórica de Mértola no período romano e na Antiguidade Tardia Virgílio Lopes

\section{8. Época Medieval}

1511 Cerâmicas islâmicas no Garb setentrional "português": algumas evidências e incógnitas Constança dos Santos / Helena Catarino / Susana Gómez / Maria José Gonçalves / Isabel Inácio / Gonçalo Lopes / Jacinta Bugalhão / Sandra Cavaco / Jaquelina Covaneiro / Isabel Cristina Fernandes / Ana Sofia Gomes 
1525 Contributo para o conhecimento da cosmética islâmica, em Silves, durante a Idade Média Rosa Varela Gomes

1537 Yábura e o seu território - uma análise histórico-arqueológica de Évora entre os séculos VIII-XII José Rui Santos

1547 A encosta sul do Castelo de Palmela - resultados preliminares da escavação arqueológica Luís Filipe Pereira / Michelle Teixeira Santos

1559 A igreja de São Lourenço (Mouraria, Lisboa): um conjunto de silos e de cerâmica medieval islâmica

Andreia Filipa Moreira Rodrigues

1571 O registo material de movimentações populacionais no Médio Tejo, durante os séculos XII-XIII. Dois casos de "sunken featured buildings", nos concelhos de Cartaxo e Torres Novas Marco Liberato / Helena Santos / Nuno Santos

1585 O nordeste transmontano nos alvores da Idade média. Notas para reflexão Ana Maria da Costa Oliveira

1601 Sepulturas escavadas na rocha do Norte de Portugal e do Vale do Douro: primeiros resultados do Projecto SER-NPVD

Mário Jorge Barroca / César Guedes / Andreia Arezes / Ana Maria Oliveira

1619 "Portucalem Castrum Novum" entre o Mediterrâneo e o Atlântico: o estudo dos materiais cerâmicos alto-medievais do arqueossítio da rua de D. Hugo, nํ. 5 (Porto) João Luís Veloso

1627 A Alta Idade Média na fronteira de Lafões: notas preliminares sobre a Arqueologia no Concelho de Vouzela

Manuel Luís Real / Catarina Tente

1641 Um conjunto cerâmico medieval fora de portas: um breve testemunho aveirense Susana Temudo

${ }_{1651}$ Os Lóios do Porto: uma perspetiva integrada no panorama funerário da Baixa Idade Média à Época Moderna em meios urbanos em Portugal

Ana Lema Seabra

1659 O Caminho Português Interior de Santiago como eixo viário na Idade Média Pedro Azevedo

1665 Morfologia Urbana: Um exercício em torno do Castelo de Ourém André Donas-Botto / Jaqueline Pereira

1677 Intervenção arqueológica na Rua Marquês de Pombal/Largo do Espírito Santo (Bucelas, Loures)

Florbela Estêvão / Nathalie Antunes-Ferreira / Dário Ramos Neves / Inês Lisboa

1691 O Cemitério Medieval do Poço do Borratém e a espacialidade funerária na cidade de Lisboa Inês Belém / Vanessa Filipe / Vasco Noronha Vieira / Sónia Ferro / Rodrigo Banha da Silva

1705 Um Espaço Funerário Conventual do séc. XV em Lisboa: o caso do Convento de São Domingos da Cidade Sérgio Pedroso / Sílvia Casimiro / Rodrigo Banha da Silva / Francisca Alves Cardoso

\section{9. Época Moderna e Contemporânea}

1721 Arqueologia Moderna em Portugal: algumas reflexões críticas em torno da quantificação de conjuntos cerâmicos e suas inferências históricas e antropológicas Rodrigo Banha da Silva / André Bargão / Sara da Cruz Ferreira

1733 Faianças de dois contextos entre os finais do século XVI e XVIII do Palácio dos Condes de Penafiel, Lisboa

Martim Lopes / Tomás Mesquita 
1747 Um perfil de consumo do século XVIII na foz do Tejo: O caso do Mercado da Ribeira, Lisboa Sara da Cruz Ferreira / Rodrigo Banha da Silva / André Bargão

1761 Os Cachimbos dos Séculos XVII e XVIII do Palácio Mesquitela e Convento dos Inglesinhos (Lisboa)

Inês Simão / Marina Pinto / João Pimenta / Sara da Cruz Ferreira / André Bargão / Rodrigo Banha da Silva

1775 "Tomar os fumos da erua que chamão em Portugal erua sancta». Estudo de Cachimbos provenientes da Rua do Terreiro do Trigo, Lisboa

Miguel Martins de Sousa / José Pedro Henriques / Vanessa Galiza Filipe

1787 Cachimbos de Barro Caulínitico da Sé da Cidade Velha (República de Cabo Verde)

Rodrigo Banha da Silva / João Pimenta / Clementino Amaro

1801 Algumas considerações sobre espólio não cerâmico recuperado no Largo de Jesus (Lisboa) Carlos Boavida

1815 Adereços de vidro, dos séculos XVI-XVIII, procedentes do antigo Convento de Santana de Lisboa (anéis, braceletes e contas)

Joana Gonçalves / Rosa Varela Gomes / Mário Varela Gomes

1837 Da ostentação, luxo e poder à simplicidade do uso quotidiano: arqueologia e simbologia de joias e adornos da Idade Moderna Portuguesa Jéssica Iglésias

1849 Os amuletos em Portugal - dos objetos às superstições: o coral vermelho Alexandra Vieira

1865 Cerâmicas de Vila Franca de Xira nos séculos XV e XVI Eva Pires

1879 «Não passa por teu o que me pertence». Marcas de individualização associadas a faianças do Convento de Nossa Senhora de Aracoeli, Alcácer do Sal Catarina Parreira / Íris Fragoso / Miguel Martins de Sousa

1891 Cerâmica de Leiria: alguns focos de produção

Jaqueline Pereira / André Donas-Botto

1901 Os Fornos na Rua da Biquinha, em Óbidos Hugo Silva / Filipe Oliveira

1909 A casa de Pêro Fernandes, contador dos contos de D. Manuel I: o sítio arqueológico da Silha do Alferes, Seixal (século XVI) Mariana Nunes Ferreira

1921 O Alto da Vigia (Sintra) e a vigilância e defesa da costa Alexandre Gonçalves / Sandra Santos

1937 O contexto da torre sineira da Igreja de Santa Maria de Loures Paulo Calaveira / Martim Lopes

1949 A Necrópole do Hospital Militar do Castelo de São Jorge e as práticas funerárias na Lisboa de Época Moderna Susana Henriques / Liliana Matias de Carvalho / Ana Amarante / Sofia N. Wasterlain

1963 SAND - Sarilhos Grandes Entre dois Mundos: o adro da Igreja e a Paleobiologia dos ossos humanos recuperados

Paula Alves Pereira / Roger Lee Jesus / Bruno M. Magalhães

1975 Expansão urbana da vila de Cascais no século XVII e XVIII: a intervenção arqueológica na Rua da Vitória no 15 a 17

Tiago Pereira / Vanessa Filipe

1987 Novos dados para o conhecimento do Urbanismo de Faro em época Moderna Ana Rosa 
1995 Um exemplo de Arqueologia Urbana em Alcoutim: o Antigo Edifício dos CTT Marco Fernandes / Marta Dias / Alexandra Gradim / Virgílio Lopes / Susana Gómez Martínez

2007 Palácio dos Ferrazes (Rua das Flores/Rua da Vitória, Porto): a cocheira de Domingos Oliveira Maia

Francisco Raimundo

2021 As muitas vidas de um edifício urbano: História, Arqueologia e Antropologia no antigo Recreatório Paroquial de Penafiel Helena Bernardo / Jorge Sampaio / Marta Borges

2035 O convento de Nossa Senhora da Esperança de Ponta Delgada: o contributo da arqueologia para o conhecimento de um monumento identitário João Gonçalves Araújo / N’Zinga Oliveira

2047 Arqueologia na ilha do Corvo... em busca da capela de Nossa Senhora do Rosário Tânia Manuel Casimiro / José Luís Neto / Luís Borges / Pedro Parreira

2059 Perdidos à vista da Costa. Trabalhos arqueológicos subaquáticos na Barra do Tejo Jorge Freire / José Bettencourt / Augusto Salgado

2071 Arqueologia marítima em Cabo Verde: enquadramento e primeiros resultados do projecto CONCHA

José Bettencourt / Adilson Dias / Carlos Lima / Christelle Chouzenoux / Cristóvão Fonseca / Dúnia Pereira / Gonçalo Lopes / Inês Coelho / Jaylson Monteiro / José Lima / Maria Eugénia Alves / Patrícia Carvalho / Tiago Silva

2085 Trabalhos arqueológicos na Cidade Velha (Ribeira Grande de Santiago, Cabo Verde): reflexões sobre um projecto de investigação e divulgação patrimonial André Teixeira / Jaylson Monteiro / Mariana Mateus / Nireide Tavares / Cristovão Fonseca / Gonçalo C. Lopes / Joana Bento Torres / Dúnia Pereira / André Bargão / Aurélie Mayer / Bruno Zélie / Carlos Lima / Christelle Chouzenoux / Inês Henriques / Inês Pinto Coelho / José Lima / Patrícia Carvalho / Tiago Silva

2103 A antiga fortificação de Quelba / Khor Kalba (E.A.U.). Resultados de quatro campanhas de escavações, problemáticas e perspectivas futuras Rui Carita / Rosa Varela Gomes / Mário Varela Gomes / Kamyar Kamyad

2123 Colónias para homens novos: arqueologia da colonização agrária fascista no noroeste ibérico Xurxo Ayán Vila / José Mạ . Señorán Martín 


\title{
A ARQUEOBOTÂNICA NO CASTRO DE GUIFÕES (MATOSINHOS, NOROESTE DE PORTUGAL): O PRIMEIRO ESTUDO CARPOLÓGICO
}

\author{
Luís Seabra ${ }^{1}$, Andreia Arezes ${ }^{2}$, Catarina Magalhães ${ }^{3}$, José Varela ${ }^{4}$, João Pedro Tereso ${ }^{5}$
}

\begin{abstract}
RESUMO
O Castro de Guifões (Matosinhos, Noroeste de Portugal), estrategicamente implantado junto ao Rio Leça, tem sido alvo de estudo por vários arqueólogos, desde os finais do século XIX. Em 2016, tiveram início novas escavações arqueológicas que levaram à recolha de amostras sedimentares para análises arqueobotânicas. Neste trabalho serão divulgados os resultados do estudo carpológico (frutos e sementes), de amostras provenientes de quatro campanhas. Este estudo cobre uma ampla diacronia, que se estende entre a Idade do Ferro e a Antiguidade Tardia, bem como um conjunto diverso de contextos arqueológicos. Os resultados revelaram um predomínio de cereais, principalmente de milho-miúdo e de trigo de grão nu. O centeio e, sobretudo, o milho-painço e a cevada, surgiram em número mais reduzido.
\end{abstract}

Palavras-chave: Castro de Guifões, Carpologia, Idade do Ferro, Período Augustano, Antiguidade Tardia.

\begin{abstract}
The Castro de Guifões (Matosinhos, Noroeste de Portugal), strategically settled nearby the river Leça, has been studied by several archaeologists, since the end of the XIX century. In 2016, new archaeological excavations led to the recovery of sediment samples for archaeobotanical analyses. This work presents the carpological results (fruits and seeds) of samples from four campaigns, covering a large time-span, between the Iron Age and the Late Antiquity, as well as a diverse set of archaeological contexts. The results showed a predominance of cereals, mainly broomcorn millet and naked wheat. Rye, and above all foxtail millet and barley appeared in smaller amounts.
\end{abstract}

Keywords: Castro de Guifões, Carpology, Iron Age, Age of Augustus, Late Antiquity.

\footnotetext{
1. InBIO - Rede de Investigação em Biodiversidade e Biologia Evolutiva, Lab. Associado; CIBIO - Centro de Investigação em Biodiversidade e Recursos Genéticos, Universidade do Porto; lc_pacos@hotmail.com

2. CITCEM - Centro de Investigação Transdisciplinar "Cultura, Espaço e Memória”; Departamento de Ciências e Técnicas do Património da Faculdade de Letras da Universidade do Porto; aarezes@letras.up.pt

3. FLUP - Aluna no Mestrado em Arqueologia da Faculdade de Letras da Universidade do Porto; omcatarina@gmail.com

4. CMM - Câmara Municipal de Matosinhos; jose.varela@cm-matosinhos.pt

5. InBIO - Rede de Investigação em Biodiversidade e Biologia Evolutiva, Lab. Associado; CIBIO - Centro de Investigação em Biodiversidade e Recursos Genéticos, Universidade do Porto; UNIARQ - Centro de Arqueologia da Universidade de Lisboa; Faculdade de Letras da Universidade de Lisboa; MHNC-UP-Museu de História Natural e Ciência da Universidade do Porto; jptereso@gmail.com
} 


\section{INTRODUÇÃO}

Nos últimos anos, tem-se assistido a um incremento de estudos carpológicos no Norte de Portugal, particularmente em sítios arqueológicos ocupados entre a Idade do Ferro e o Período Romano (e.g. Tereso, 2012; Leite, Tereso \& Sanches, 2018; Seabra \& alii, 2018), tendo estes estudos incidido, quase exclusivamente, sobre áreas não costeiras.

A faixa costeira do norte português encontra-se sub-representada, sendo as análises carpológicas desenvolvidas no Castro de São de Lourenço uma exceção. Neste sítio foi recuperado um pequeno conjunto de macrorrestos vegetais, em níveis do século IV d.C. (Tereso, 2012). Por outro lado, na costa da Galiza, nomeadamente nas Rias Baixas, observa-se um maior incremento de estudos e conjuntos carpológicos, principalmente em sítios habitados durante a Idade do Ferro e a viragem da era (Teira-Brión, 2019).

A implementação de habitats na faixa costeira atlântica, assume particular relevância, sobretudo pelo elevado potencial económico possibilitado pelo eventual papel destes sítios nas rotas comerciais entre o litoral e o interior. Entre estes, encontra-se o Castro de Guifões (Matosinhos), localizado junto ao antigo estuário do Rio Leça, sendo que na Antiguidade, o rio seria navegável até ao sopé do Castro.

O novo projeto de investigação recentemente iniciado no Castro de Guifões, incidiu sobre uma área de cota baixa, junto ao rio, conhecida como "Campo da Ponte” (Figura 1). Os trabalhos aqui desenvolvidos, incorporaram desde cedo uma vertente multidisciplinar, através da recolha de amostras sedimentares, para o desenvolvimento de estudos arqueobotânicos (Arezes \& Varela, 2017). Aqui, serão divulgados os resultados da análise carpológica. Esta tem como objetivos principais contribuir para compreensão do sítio e dos respetivos depósitos arqueológicos, bem como produzir informação sobre práticas agrícolas e o ambiente ruderal, durante um intervalo de ocupação do Castro de Guifões, e, consequentemente, a sua integração nas dinâmicas socioeconómicas e de ocupação da faixa costeira do Noroeste Peninsular, entre a Idade do Ferro e a Antiguidade Tardia.

\section{SÍTIO ARQUEOLÓGICO}

O Castro de Guifões, também chamado de Monte Castêlo, inscreve-se administrativamente na União de Freguesias de Custóias, Leça do Balio e Guifões, concelho de Matosinhos, na margem esquerda do Rio Leça. O Castro implanta-se precisamente junto ao rio, no local onde deixa de correr num meandro mais apertado entre escarpas rochosas e se começa a abrir num largo estuário em direção ao Atlântico, do qual dista apenas cerca de três quilómetros. A importância arqueológica do sítio decorre da relação próxima que estabelece com o mar e o rio (Arezes, 2019) estando documentada a navegabilidade do troço final do Leça, pelo menos, até ao século XVI (Varela, 2013). Ocupando uma área de cerca de nove hectares, surge rodeado por espaços aplanados que albergam solos de boa potencialidade agrícola.

Os dados conhecidos sobre este sítio apontam para uma ocupação contínua, que recuará ao Bronze Final, passando pela Idade do Ferro, até à Antiguidade Tardia (Varela, 2011). E, na verdade, há muito que os achados de materiais neste local chamam a atenção para a sua importância arqueológica, captando a atenção de investigadores como Francisco Martins Sarmento, José Leite Vasconcelos ou Rocha Peixoto, entre outros (Cleto \& Varela, 1999).

Já em meados do século XX Joaquim Neves dos Santos dedica uma parte significativa do seu tempo e dos seus bens a estudar este Castro, procedendo a diversas escavações, quase sempre como forma de minimização de impactos causados pela abertura de caminhos ou pela exploração agrícola dos terrenos a ele afetos. Entre 1961 e 1962 promove uma intervenção na base do Monte Castêlo, muito perto da margem do Rio Leça, numa zona a que chamavam de "Campo da Ponte" (Santos, 1963). Trata-se de uma área de cerca de $800 \mathrm{~m}^{2}$, constituída principalmente por depósitos aluvionares aqui assentados pela ação das cheias cíclicas do Rio Leça.

Os trabalhos ali desencadeados tinham como objetivo concretizar o registo arqueológico dos vestígios ali patentes antes da destruição a que o arroteamento inevitavelmente conduziria. Estes colocaram à vista um conjunto dotado de vários compartimentos (Santos, 1995/96), associados à presença de um acervo muito significativo de materiais cerâmicos, predominantemente enquadráveis no Baixo Império e Antiguidade Tardia. Entre estes materiais destacam-se a Sigillata Africana Clara D e C, os pratos de Sigillata Bracarense Tardia, ou ainda os almofarizes com vidrado interior (Almeida \& Santos, 1975; Fernández \& Morais, 2012; Arezes \& Varela, 2017).

Em 2016 arrancou o Projecto de Investigação Plurianual em Arqueologia designado "GUIFARQ - 
Projeto de Investigação Arqueológica de Guifões" (presentemente, na sua II edição), apoiado numa parceria estabelecida entre a Câmara Municipal de Matosinhos e a Faculdade de Letras da Universidade do Porto. Uma das vertentes do referido projeto prendia-se especificamente com a escavação arqueológica de uma parcela do terreno do já mencionado "Campo da Ponte" (Figura 1): concretamente, uma parcela contígua àquela onde, entre 1961 e 1962, Joaquim Neves dos Santos promovera trabalhos (Arezes \& Varela, 2017).

Após a concretização das primeiras quatro campanhas de escavação anuais no âmbito do Projeto GUIFARQ, começam a avolumar-se os dados recolhidos, ainda que a dimensão das interrogações suscitadas pelas modalidades específicas de ocupação do sítio se mantenha ampla. Todavia, algumas das evidências, sobretudo as relativas à perturbação desta zona aplanada, são sintomáticas desde 2016 (Arezes \& Varela, 2017). Com efeito, num universo de nove quadrículas já intervencionadas (cada uma das quais com $16 \mathrm{~m}^{2}$ de área) há um denominador comum a apontar e que se prende com o facto de vários níveis (naturalmente, com destaque para os superficiais) demonstrarem a ocorrência de revolvimentos; a tal acresce ainda a deposição de aterros que terão sido deslocados, no sentido de nivelar e, eventualmente, melhorar a capacidade agrícola do "Campo da Ponte". Na verdade, as lavras do terreno surgem plenamente comprovadas, não apenas em documentação fotográfica, mas também na presença de alguns negativos que parecem coadunar-se com a passagem recorrente de arados ou mecanismos equivalentes. É, pois, na combinação de tais circunstâncias, que radica a mescla de inclusões materiais atestada: uma mescla que, em algumas unidades estratigráficas, compreende artefactos integráveis num universo temporal que se estende desde a Idade do Ferro até à época Contemporânea (Arezes \& Varela, 2017).

Em contrapartida, o aprofundamento da escavação permitiu a exumação de um complexo conjunto de construções, representativos de diferentes momentos de ocupação deste espaço. Até ao momento, as mais antigas estruturas identificadas, [133] e [170], constam, respetivamente, de uma lareira de argila pisoteada, dotada de círculos impressos, e de uma outra, contígua, mas isenta de decoração (Arezes \& Varela, 2018; Arezes, 2019). Estas lareiras integrariam o espaço interior de uma antiga cabana da Idade do Ferro, entretanto cortada, e à qual se so- brepôs posteriormente um dos alinhamentos, [20], pertencentes a uma construção de planta tendencialmente ortogonal (Compartimento 2). Em posição sensivelmente simétrica, mas a poente da área de intervenção, foi parcialmente desvelado [63], um dispositivo constituído por blocos de médio porte, e dotado de cunhal muito bem esquadriado (Arezes \& Varela, 2018). Aliás, o lanço que arranca a partir do cunhal e se prolonga no sentido sudoeste/nordeste poderá ter sido utilizado como base de apoio para a construção ou reformulação tardia deste Compartimento. Com efeito, o alinhamento [15], que integrava, juntamente com [35], um único dispositivo de aparelho menos conseguido e atualmente truncado, segue a orientação de [63], sobrepondo-se a este. No interior do Compartimento 2, foram já diversos os estratos detetados, mas destacamos [19], caracterizado pela significativa presença de dolia, e de alguns exemplares de sigillatas africanas Clara D (Arezes \& Varela, 2017).

Sensivelmente a norte da referida construção, foi possível detetar um outro dispositivo (Compartimento 1), que apresentava a particularidade de exibir cantos arredondados e abarcava, a somar a vários outros depósitos, um consideravelmente enegrecido pela presença abundante de cinzas e carvões, [25]. Face ao exposto, comprova-se que o "Campo da Ponte", situado na periferia do Castro e muito próximo da margem do Rio Leça, foi efetivamente pautado por sucessivos momentos de construção, arrasamento e reconstrução, sem nunca quebrar a relação primordial que manteve com o curso fluvial.

\section{MATERIAIS E MÉTODOS}

\subsection{Amostragem e descrição dos contextos ar- queológicos}

Entre as campanhas de 2016 e 2019, foram recolhidas 191 amostras para análises arqueobotânicas. 67 correspondem a amostras sedimentares, perfazendo um total de 393,6 L de sedimento. Destas, apenas uma amostra foi crivada. As restantes foram processadas através de flutuação manual, com recurso a uma malha de o,5 mm. 124 amostras refletem recolhas manuais, recuperadas de forma selecionada pela equipa de campo.

Para este artigo foram consideradas apenas as U.E. que providenciaram elementos carpológicos quantificáveis (ver metodologia laboratorial). Deste modo, contabilizam-se 111 amostras, oriundas de 28 U.E., 
identificadas em oito quadrículas (Tabela 1), sendo que 60 amostras constituem $383,7 \mathrm{~L}$ de sedimento. As remanescentes 51 amostras constituem recolhas manuais.

Os depósitos em estudo representam um conjunto heterogéneo de contextos arqueológicos, provenientes de diferentes áreas do "Campo da Ponte", designadamente, do interior de dois compartimentos, da área que medeia entre ambos e respetivos espaços limítrofes (Tabela 1, Figura 1). Abrangem uma diacronia de ocupação ampla, entre a Idade do Ferro e a Antiguidade Tardia. Em várias ocasiões, não foi possível restringir a um único momento de ocupação e, por esse motivo, foi necessário atribuir um faseamento mais abrangente (e.g. Idade do Ferro/ Período Romano, Período Romano/Antiguidade Tardia). Não obstante, foi possível distinguir três fases principais: $1^{\circ}$ ) Idade do Ferro, $2^{\circ}$ ) Período Augustano e $3^{\circ}$ ) Antiguidade Tardia (Tabela 1 ).

$\left.\mathbf{I}^{\circ}\right)$ As U.E. [65], [159] e [163] representam momentos antigos de ocupação, correlacionáveis com a Idade do Ferro. Nestas camadas, não foi percetível a presença de espólio arqueológico de qualquer outra cronologia. Correspondem a depósitos dispersos, recolhidos na zona este do sítio arqueológico, em zonas exteriores ao compartimento 2, provavelmente construído ou reformulado na Antiguidade Tardia (Tabela 1, Figura 1). Foi recolhido um total de $16 \mathrm{~L}$ de sedimento, em que 14 destes provêm da U.E. [65], uma camada que cobria duas lareiras, U.E. [133] e [177], da Idade do Ferro (Arezes \& Varela, 2018; Arezes, 2019).

$\left.2^{\circ}\right)$ A segunda fase retrata um momento circunscrito da ocupação alto-imperial no "Campo da Ponte", no Período Augustano. Presente em cinco U.E.: [26], [38], [43], [47] e [93], com características distintas (Pisos/Pavimentos, depósito disperso, enchimentos). Provenientes do interior do compartimento 2 e de espaços próximos a este (Tabela 1, Figura 1). Destas camadas foram recolhidos $84 \mathrm{~L}$ de sedimento. Estes depósitos integravam conjuntos artefactuais compatíveis com o período de transição compreendido entre o século I a.C. e I d.C., com destaque para as cerâmicas micáceas de produção local e para materiais caracteristicamente romanos.

$\left.3^{\circ}\right)$ Nove U.E.: [11], [17], [21], [23], [25], [41], [49], [184], [185] encontram-se associadas à Antiguidade Tardia. Trata-se da fase com maior repre- sentação e esforço de amostragem (156,5 L). Estas unidades são oriundas do interior dos dois compartimentos identificados e de zonas próximas (Tabela 1, Figura 1). A maior parte destas camadas corresponde a depósitos dispersos. Algumas (e.g. [11], [25], [184]), incluem materiais de outros períodos cronológicos, sendo de admitir a ocorrência de revolvimentos. Contudo, as relações estratigráficas entre os depósitos, bem como a globalidade do acervo, indicam estarmos perante níveis da Antiguidade Tardia. Relativamente às restantes camadas, tanto o espólio como o contexto arqueológico não permitiram, de uma forma clara, a associação a um único momento de ocupação. Foram estabelecidas outras categorias cronológicas, que englobam duas ou até mesmo três fases (Tabela 1). Independentemente das dificuldades de interpretação cronológica que estes depósitos podem suscitar, os resultados obtidos serão incluídos neste estudo carpológico.

\subsection{Metodologia laboratorial}

A triagem das frações leves foi realizada com o auxílio de uma lupa binocular. Para a caracterização e identificação dos vestígios carpológicos utilizou-se bibliografia especializada, sobretudo atlas morfológicos (e.g. Hillman \& alii, 1996; Jacomet, 2006; Neef, Cappers \& Bekker, 2012). Para o diagnóstico taxonómico, recorreu-se igualmente à comparação com espécimes atuais, através da coleção de referência presente no Herbário da Universidade do Porto (PO), localizado nas instalações do Museu de História Natural e Ciência da Universidade do Porto (MHNC-UP) e do CIBIO.

Devido ao seu elevado peso e volume, e para tornar o trabalho laboratorial exequível, foi necessário subamostrar 31 amostras (Tabela 2). A fração leve de cada amostra foi divida por dimensão, através de uma coluna de crivos, com malhas de $2 \mathrm{~mm}, 1 \mathrm{~mm}$ e $0,5 \mathrm{~mm}$. Em relação à malha de $2 \mathrm{~mm}$, foi realizada uma triagem integral em todas as amostras. No caso das malhas de $1 \mathrm{~mm}$ e $0,5 \mathrm{~mm}$, foi necessário aplicar, de um modo regular, a subamostragem. Na realização deste procedimento, procurámos obter valores consistentes. Assim, sobre a malha de crivos de 1 $\mathrm{mm}$ foi analisado em média 5,8 gramas, enquanto sobre a malha de $0,5 \mathrm{~mm} \mathrm{2,3}$ gramas.

$\mathrm{Na}$ generalidade, tanto as amostras realizadas na íntegra como as subamostradas, mostraram poucos elementos carpológicos (ver Resultados). Assim, 
estimar o número de sementes/frutos existentes na totalidade da amostra extrapolando a partir dos resultados obtidos, tendo em conta a percentagem analisada da amostra, poderia sobrestimar a presença de alguns táxones, pelo que se optou por não efetuar qualquer extrapolação. Deste modo, os resultados apresentados na Tabela 3 refletem unicamente valores efetivos, identificados nas subamostras.

Neste estudo foram quantificados elementos carpológicos unitários, fragmentos com escutelo/hilo e escutelos individuais. Excetua-se apenas alguns carporrestos, que por fornecerem algum nível de detalhe taxonómico (género ou espécie) e pelo facto de terem aparecido apenas fragmentados, foram incluídos nos resultados (Tabela 3).

Para efeitos contabilísticos, no grupo dos cereais, dois fragmentos longitudinais foram quantificados como uma unidade (grão). Um procedimento similar foi aplicado às leguminosas, tendo dois cotilédones (metades) sido determinados como uma semente. Relativamente às inflorescências, foram contabilizados segmentos e fragmentos de ráquis de centeio, nós de ráquis de trigo nu e bases de lema de cevada.

\section{RESULTADOS}

O estudo carpológico realizado no "Campo da Ponte", revelou um conjunto de pequena dimensão (625 carporrestos), caracterizado na sua maioria pela presença de grãos de cereais (Tabela 3 ). Em termos quantitativos, verifica-se um predomínio de milho-miúdo (Panicum miliaceum), seguido do trigo de grão nu (Triticum aestivum/durum), centeio (Secale cereale), milho-painço (Setaria italica) e cevada (Hordeum vulgare), este último em números esporádicos.

Foi recuperada uma quantidade considerável de grãos de milho, identificados como Panicum/Setaria (52). Apesar de não ter sido possível uma diferenciação, este número reforça a presença dos milhos no registo carpológico. No entanto, esta maior representação dos milhos, designadamente do milho-miúdo, não deve ser sobrevalorizada. Os grãos de milho apresentam dimensões mais reduzidas do que os restantes cereais aqui identificados, sendo que, em termos de volume, este predomínio deixa-se de verificar, principalmente em comparação com o trigo nu.

Para além dos grãos, foram recolhidas inflorescências de cereal. É de realçar um registo significativo de nós de ráquis de trigo nu (6o), inclusive, maior do que os grãos (51). Em número mais reduzido, foram recolhidos 15 segmentos e cinco fragmentos de ráquis de centeio, bem como duas bases de lema de cevada. Este estudo demonstrou a presença de uma única espécie de leguminosa cultivada. No "Campo da Ponte", foram recuperadas cinco favas (Vicia faba). Não podemos descartar que, considerando a dimensão das sementes, as leguminosas identificadas como Vicia/Lathyrus correspondam a cultivos, contudo o seu estado de conservação não permitiu uma interpretação mais sólida.

Salienta-se o registo de grãos de aveia (Avena sp.). Identificados ao nível do género devido à ausência das inflorescências, não foi possível compreender se estamos perante elementos cultivados ou silvestres. A presença das inflorescências é crucial para esta clarificação (Ruas \& Pradat, 2001; Jacomet, 2006). Apesar de estarmos perante um conjunto carpológico de baixa dimensão, os resultados demonstraram alguma diversidade. Além de cereais e leguminosas, foram recuperados alguns vestígios de frutos. Em especial, dois fragmentos de caroço de pêssego (Prunus persica) e fragmentos de castanha (Castanea sativa), que deverão corresponder a elementos cultivados. Em relação aos dois aquénios de amo$\mathrm{ra} /$ framboesa (Rubus sp.), estes podem tratar-se de vestígios silvestres e/ou cultivados. Já o único fragmento de cotilédone de bolota (Quercus sp.) identificado trata-se de um carporresto silvestre.

Os restantes vestígios carpológicos correspondem, da mesma maneira, a elementos silvestres. Foram recolhidas algumas gramíneas (e.g. Poaceae, Festuca/Lolium) e leguminosas (e.g. Ornithopus sp., Fabaceae) silvestres. Destaca-se a presença frequente de camarinha (Corema album), sendo este o macrorresto silvestre em maior número (28). Morrião (Anagallis arvenses), saramago (Raphanus raphanistrum), verbena (Verbena officinalis) ou beldroega (Portulaca oleracea) são outros exemplos de carporrestos silvestres identificados no "Campo da Ponte". Tal como mencionado previamente, este estudo demonstrou um conjunto carpológico de pequena extensão. Cada unidade estratigráfica apresentou sempre um conteúdo inferior a 100 carporrestos. 13 U.E. revelaram, individualmente, menos de dez elementos (Tabela 3). Os vestígios carpológicos são oriundos de depósitos significativamente heterogéneos entre si e estes abarcam uma larga diacronia, desde a Idade do Ferro até à Antiguidade Tardia. Como tal, 
a análise da distribuição e interpretação dos macrorrestos pelo sítio, bem como o respetivo faseamento exige cautelas. Apesar disto, e tendo em contas as fases de ocupação estabelecidas (ver Amostragem e descrição dos contextos arqueológicos) é possível tecer algumas considerações:

A fase mais antiga, da Idade do Ferro, é representada por 28 elementos carpológicos. Este pequeno conjunto é coincidente com o baixo volume de sedimento recolhido (16 L). A maioria dos macrorrestos provém da U.E. [65], a camada alvo do maior esforço de amostragem (14 L). Refere-se a presença de seis grãos de milho-miúdo e um grão de milho-painço, e um nó de ráquis de trigo nu. Dentro do grupo das plantas silvestres, evidencia-se o registo de nove sementes de camarinha.

Um total de 111 carporrestos foi identificado em depósitos adscritos ao Período de Augusto. No entanto, tendo em conta o volume recolhido (84 L), trata-se de uma baixa quantidade de vestígios carpológicos. Há um predomínio dos cereais, nomeadamente de 24 grãos de milho-miúdo, seguidos de 21 nós de ráquis e oito grãos de trigo nu. Num plano menos substancial, confere-se o registo de cinco grãos de milho-painço, uma base de lema e um grão de cevada, tal como um segmento de ráquis de centeio. O remanescente é composto por outras gramíneas (e.g. aveia, Panicoideae), leguminosas (e.g. Ornithopus sp., Vicia/Lathyrus) e por plantas silvestres (e.g. camarinha, saramago, Asteraceae tipo Chrysanthemum). Estes vestígios encontram-se, do mesmo modo, representados em quantidades pouco relevantes.

O terceiro momento de ocupação (Antiguidade Tardia), revelou um conjunto carpológico um pouco mais expressivo e diverso, mas sem transcender de forma muito óbvia. Em nove U.E., que configuram 156,5 L de sedimento, foram recuperados 285 vestígios carpológicos. Tal como na fase anterior, assiste-se a um domínio dos cereais. O milho-miúdo é predominante (86 grãos), seguido de uma quantidade considerável de grãos (28), segmentos (14) e fragmentos de ráquis (quatro) de centeio, bem como de grãos (14) e nós de ráquis (11) de trigo nu. Em segundo plano, surgem o milho-painço (oito grãos) e a cevada (quatro grãos). Sobre os restantes carporrestos, em comparação com as fases anteriores, salienta-se algumas diferenças: a identificação de duas favas, assim como o registo de outros frutos, designadamente um fragmento de caroço de pêssego, fragmentos de castanha e um fragmento de cotilédone de bolota.
Em relação aos conjuntos carpológicos provenientes de camadas associadas a mais do que um momento de ocupação (Idade do Ferro/Período Romano, Período Romano/Antiguidade Tardia, Idade do Ferro/Período Romano/Antiguidade Tardia), no geral, observa-se um panorama semelhante ao já referido (Tabela 3), sendo as diferenças pouco significativas para serem aqui detalhadas.

\section{DISCUSSÃO}

\subsection{O contexto arqueológico}

Muitos dos vestígios carpológicos recolhidos no "Campo da Ponte" provêm de depósitos arqueológicos de difícil caracterização e interpretação, essencialmente deposições secundárias ou depósitos formados após o abandono do local (Tabela 1). O seu enquadramento cronológico é igualmente complexo, visto que das 28 U.E. em estudo, 11 dispõem de um faseamento dúbio, entre dois ou três momentos de ocupação. Para além disto, apesar da atribuição de uma única fase às restantes camadas, algumas revelaram evidências de intrusões e/ou revolvimentos (e.g. [11], [17], [21], [25], [43], [184]).

O milho-miúdo, o milho-painço e o trigo nu foram identificados nas três fases principais de ocupação do sítio. A cevada não foi recuperada, unicamente, na $1^{\circ}$ fase de ocupação. No entanto, esta é representada por um volume reduzido de sedimento. Além disto, foram recuperados grãos de cevada na fase Idade do Ferro/Período Romano, não sendo assim de excluir, a hipótese da cevada ter sido consumida no local durante a Idade do Ferro, à semelhança do que tem sido identificado em outros sítios da região.

O aparecimento do centeio aparenta ser a exceção mais relevante. Os registos mais antigos (U.E. [26] e [46], apontam para a sua ocorrência entre o final da Idade do Ferro e o Período Augustano, no "Campo da Ponte". Contudo, trata-se de um registo muito esporádico. No piso/pavimento [26], atribuído ao período de Augusto, foi identificado um segmento de ráquis. No caso da U.E. [46], um dos enchimentos da fossa [42], que integrava material cerâmico do final da Idade do Ferro / arranque da ocupação Romana, foi encontrado um fragmento de ráquis de centeio. Sendo o centeio (grãos e ráquis) mais frequente nos níveis da Antiguidade Tardia, os exíguos vestígios dos níveis antigos, poderão resultar de intrusões.

Algo semelhante poderá ser apontado à presença do pêssego, também identificado na U.E. [46]. Este 
depósito, incluía o maior número (78) e diversidade de elementos carpológicos (22 táxones). Trata-se de um de dois depósitos de enchimento de uma fossa (interface [42]) que deverão resultar do uso desta estrutura como lixeira. O depósito inferior (U.E. 46), aqui referido, tem materiais da Idade do Ferro / Período Romano, enquanto que o depósito superior da mesma estrutura (U.E. 41) apresenta materiais da Antiguidade Tardia. Como tal, não podemos excluir a possibilidade de intrusões entre os sedimentos desta estrutura. Um outro fragmento de caroço de pêssego foi detetado num depósito da Antiguidade Tardia (U.E. [25]).

Em relação aos restantes elementos carpológicos, estes aparentam enquadrar-se no padrão geral. Independentemente da fase ou do contexto de proveniência, estes são parcos em número. Destaca-se apenas que alguns táxones (e.g. aveia, camarinha), estão presentes em número considerável e em todos os momentos de ocupação identificados no "Campo da Ponte".

\subsection{Cultivos}

Tal como referido anteriormente, a dificuldade em atribuir um enquadramento cronológico seguro aos depósitos arqueológicos, obriga a cautelas na interpretação dos vestígios carpológicos. Em suma, os resultados revelam uma diversidade de cultivos, principalmente de cereais, tendo sido registados em proporções não muito divergentes, independentemente da fase de ocupação e do contexto em análise. Algo que impõe cuidados na realização de leituras diacrónicas, bem como na respetiva integração do Castro de Guifões nas dinâmicas socioeconómicas da faixa costeira do Noroeste Peninsular.

O milho-miúdo e o trigo nu, aparentam ter tido uma maior relevância para as comunidades que habitaram o Castro de Guifões, sendo as suas presenças significativas e transversais a todas as fases de ocupação. Por um lado, o milho-miúdo é, a nível quantitativo, o cultivo dominante, mas por outro, se tivermos em conta o volume (ver Resultados), o trigo nu é predominante. O centeio, e principalmente o milho-painço e a cevada surgem em menor expressão no registo carpológico. A maior parte destes cereais é presença recorrente na faixa costeira do Noroeste Peninsular, nos períodos em análise. Observam-se algumas diferenças, tanto para com o Castro de São Lourenço como para os sítios nas Rias Baixas, mas realçam-se dois dados importantes: a ausência de trigos de grão vestido (Triticum dicoccum e Triticum spelta) no Castro de Guifões e a inexistência de centeio nos restantes sítios mencionados.

No Castro de Guifões, os registos mais antigos de centeio apontam para o final da Idade do Ferro e o período de Augusto. Algo que não é totalmente surpreendente, pois a datação mais antiga na Península Ibérica deste cereal, remonta a meados do século I a.C. e ao povoado do Crastoeiro (Mondim de Basto) (Seabra \& alii, 2018). Contudo, o "Campo da Ponte" revelou um conjunto reduzido nestes níveis, estando grãos e ráquis presentes de forma consistente, somente na fase da Antiguidade Tardia.

A possibilidade de uma cronologia tardo-antiga para o centeio no Castro de Guifões, poderá ser fulcral para compreender estas diferenças para com o resto da faixa costeira do Noroeste Peninsular. A maioria dos sítios nas Rias Baixas com estudos carpológicos apresentam principalmente ocupações dentro da Idade do Ferro e da viragem do milénio, tal como materialidades arqueológicas muito específicas da região (Teira-Brión, 2019). Além do mais, os dados disponíveis para o resto da Península Ibérica, apontam para uma presença frequente do centeio, somente em fases mais avançadas do Período Romano (Alonso, 2005; Tereso, 2012). Neste caso, para destrinçar esta questão, de forma inequívoca, será necessário a obtenção de datações por radiocarbono sobre os vestígios de centeio do "Campo da Ponte". A presença de leguminosas foi rara. Observou-se apenas a presença da fava, em número muito baixo. Apesar desta leguminosa ser bastante comum no registo carpológico e nos mais diversos períodos cronológicos, a sua pequena expressão em comparação com os cereais é bastante comum no Noroeste Peninsular (Tereso, 2012).

Neste estudo foram observados dois frutos (pêssego e castanha), que deverão corresponder a cultivos. Em relação ao pêssego, a possibilidade de atribuir uma cronologia tardo-antiga no Castro de Guifões, é também admissível. Outras evidências de pêssego no Noroeste Peninsular, nomeadamente no sítio costeiro do Areal (Vigo) e nas termas romanas de Aquae Flaviae, atestam, do mesmo modo, o registo deste fruto em níveis da Antiguidade Tardia (Vaz \& alii, 2016; Teira-Brión, 2019). Contudo, numa necrópole romana de Bracara Augusta, foram encontrados caroços de pêssego em níveis mais antigos, nomeadamente em contextos dos séculos I e II d.C. (Vaz \& alii, aceite). Por outro lado, a presença da cas- 
tanha durante a Antiguidade Tardia no "Campo da Ponte", vai totalmente ao encontro da informação disponível para o Noroeste Peninsular. No sítio de Monte Mozinho (Penafiel) e no sítio do Areal, foram identificados frutos de castanha em níveis igualmente adscritos à Antiguidade Tardia (Vaz \& alii, 2017; Teira-Brión, 2019).

Os restantes elementos carpológicos, correspondem a vestígios silvestres. A sua interpretação é dificultada pelo número reduzido encontrado. Verifica-se alguma diversidade de táxones, sendo que muitos destes deverão corresponder a acompanhantes dos cultivos e a plantas ruderais, comuns em ambientes antropizados. Dentro deste grupo, evidencia-se a presença considerável de sementes de camarinha. Este registo permite atestar a relevância desta planta na costa atlântica, sendo cada vez mais claro que a sua distribuição na Antiguidade seria bem mais extensa do que a que se verifica na atualidade, mercê da pressão antrópica recente sobre os ambientes costeiros. Não é claro se a sua presença está diretamente relacionada com o seu consumo, mas é algo plausível, visto que as suas bagas são comestíveis (López-Dóriga, 2018).

\section{CONCLUSÃO}

Os resultados do primeiro estudo arqueobotânico realizado no Castro de Guifões demonstraram um conjunto diminuto de elementos carpológicos, caracterizado pelo predomínio dos grãos de cereais, principalmente de milho-miúdo e trigo de grão nu. O centeio, e sobretudo o milho-painço e a cevada foram registados em menor número. Para além dos grãos, foram identificadas quantidades significativas de inflorescências de cereais, designadamente nós de ráquis de trigo nu, e num plano secundário, segmentos e fragmentos de ráquis de centeio e bases de lema de cevada. O restante conjunto carpológico, revelou-se pouco frutífero, sendo de realçar o registo da fava e de alguns frutos, nomeadamente o pêssego e a castanha. Foi ainda recolhida alguma diversidade de elementos silvestres.

Estes elementos carpológicos provêm de depósitos recolhidos por todo o sítio arqueológico, refletindo uma ampla diacronia, entre a Idade do Ferro e a Antiguidade Tardia, sendo que muito destes revelaram-se de difícil contextualização e interpretação. A análise das diferentes fases de ocupação e contextos de proveniência revelou resultados pou- co heterogéneos entre si, seja a nível da diversidade como da quantidade de carporrestos encontrados. A maior parte dos cereais recolhidos no "Campo da Ponte" foram identificados, de modo simultâneo, nos três momentos principais de ocupação.

O centeio representa a exceção mais notável. Apesar de ter sido recolhido em contextos associados ao final da Idade do Ferro e ao Período Augustano, a sua presença deverá remeter-se apenas à Antiguidade Tardia. De modo similar, para os fragmentos de pêssego e de castanha admite-se uma cronologia tardo-antiga, no Castro de Guifões. O registo do centeio e ausência de trigos vestidos são as principais diferenças detetadas, em comparação com os restantes sítios costeiros do Noroeste Peninsular. Algo justificado sobretudo pela diacronia de ocupação da maior parte destes sítios, dentro da Idade do Ferro e da viragem da era, sendo o centeio frequente em momentos mais avançados do Período Romano (Alonso, 2005; Tereso, 2012; Teira-Bríon, 2019).

Este estudo representa um avanço para o conhecimento de uma área (faixa costeira), em que os estudos arqueobotânicos são ainda escassos, principalmente no Norte de Portugal. No entanto, tendo em conta a complexidade dos contextos arqueológicos analisados no "Campo da Ponte", assim como a inerente dificuldade de interpretação dos vestígios carpológicos, é crucial a continuação dos estudos arqueobotânicos. Novas análises assumem-se como fundamentais para uma melhor compreensão do uso dos recursos vegetais durante a ocupação do Castro de Guifões e para um apropriado enquadramento na faixa costeira do Noroeste Peninsular.

\section{BIBLIOGRAFIA}

ALMEIDA, Carlos Alberto Ferreira de; SANTOS, Joaquim Neves dos (1975) - Cerâmica Romana, Tardia, de Guifões. Archaeologica Opuscula. Porto. 1, pp. 49-56.

ALONSO, Natàlia (2005) - Agriculture and food from the Roman to the Islamic Period in the North-East of the Iberian peninsula: archaeobotanical studies in the city of Lleida (Catalonia, Spain). Vegetation History and Archaeobotany. 14:4, pp. 341-361.

AREZES, Andreia; VARELA, José (2017) - Castro de Guifões (Matosinhos) - das primeiras notícias aos resultados preliminares de um Projecto de Investigação. In ARNAUD, J. Morais; MARTINS, Andrea, eds. - Arqueologia em Portugal. 2017 - O Estado da questão. Lisboa: Associação dos Arqueólogos Portugueses, pp. 125-136. 
AREZES, Andreia; VARELA, José (2018) - GUIFARQ - Projecto de Investigação Arqueológica de Guifões: Relatório Final, Porto - 14 de Dezembro. Porto: texto policopiado ( $\mathrm{n}^{\circ} \mathrm{de}$ páginas: 111).

AREZES, Andreia (2019) - Castro de Guifões (Matosinhos): evidências de uma ocupação diacrónica. Revista Portuguesa de Arqueologia. Lisboa. 22, pp. 183-191.

CLETO, Joel; VARELA, José Manuel (1999) - O Castro de Guifões (Matosinhos): dos estudos de Martins Sarmento às investigações da actualidade. Revista de Guimarães. Guimarães. Volume Especial 2, pp. 467-479.

FERNÁNDEZ FERNÁNDEZ, Adolfo; MORAIS, Rui (2012) - Terra Sigillata Bracarense Tardía (Tsbt). O Grupo II das Cerâmicas de engobe vermelho não vitrificavel (Delgado 1993-94). Cerâmicas de Engobe Vermelho. Grupo II (Delgado y Morais, 2009). In BERNAL CASASOLA, Darío; RIBERA I LACOMBA, Albert, eds. - Cerámicas hispanorromanas II: producciones regionales. Cádiz: Universidad de Cádiz, pp. 131-174.

HILLMAN, Gordon; MASON, Sarah; DE MOULINS, Dominique; NESBITT, Mark (1996) - Identification of archaeological remains of wheat: the 1992 London workshop. Circaea. 12:2, pp. 195-210.

JACOMET, Stephanie (2006) - Identification of cereal remains from archaeological sites: Archaeobotany Lab. Basel: IPAS, Basel University.

LEITE, Margarida Leite; TERESO, João Pedro; SANCHES, Maria de Jesus (2018) - Cultivos da Idade do Ferro no Crasto de Palheiros: novos dados carpológicos da Plataforma Inferior Leste. Cadernos do GEEvH. 7:2, pp. 40-68.

LÓPEZ-DORIGA, Inés (2018) - The Archaeobotany and Ethnobotany of Portuguese or White Crowberry (Corema album (L.) D. Don). Ethnobiology Letters. 9:2, pp. 19-32.

NEEF, Reinder; CAPPERS, René; BEKKER, Renée (2012) Digital Atlas of Economic Plants in Archaeology. Groningen Archaeological Studies Volume 17. Groningen: Barkhuis \& Groningen University Library.

RUAS, Marie-Pierre; PRADAT, Bénédicte (2001) - Les semences découvertes: plantes attestées et origine des déchets. In Les habitats carolingiens de Montours et La Chapelle Saint-Aubert (Ille-et-Vilaine). Paris: Maison des Sciences de l'Homme (Documents d'archéologiefrançaise; 89), pp. 65-79 $+219-221$.

SANTOS, J. Neves dos (1963) - Serpentes geminadas em suástica e figurações serpentiformes do Castro de Guifões. Lucerna. Porto. 3, pp. 136-156.

SANTOS, J. Neves dos (1995/1996) - Sobre uma sítula do Castro de Guifões. Matesinus. Matosinhos. 1/2, pp. 20-22.

SEABRA, Luís; TERESO, João Pedro; BETTENCOURT, Ana M.S.; DINIS, António (2018) - Crop diversity and storage structures in the settlement of Crastoeiro (Northwest
Iberia): new approaches. Trabajos de Prehistoria. 75:2, pp. 361-378.

TEIRA-BRIÓN, Andrés (2019) - Cambio e resiliencia na agricultura e xestión de recursos vexetais no NW da Península Ibérica (10oo a.n.e.-40o d.n.e.). Santiago de Compostela: Tese de doutoramento apresentada à Faculdade de Xeografía e Historia da Universidade de Santiago de Compostela.

TERESO, João Pedro (2012) - Environmental Change, Agricultural Development and social trends in NW Iberia from the Late Prehistory To The Late Antiquity. Porto: Tese de doutoramento apresentada à Faculdade de Ciências da Universidade do Porto.

VARELA, José Manuel (2011) - Monte Castêlo (Guifões, Matosinhos). In O Rio da Memória: Arqueologia no Território do Leça, Matosinhos. Matosinhos: Câmara Municipal de Matosinhos, pp. 108-110 e 142-145.

VARELA, José Manuel (2013) - O Sítio do Monte Castêlo (Guifões, Matosinhos), o Rio Leça e as Navegações na Antiguidade. al-Madan. Almada. Série II. 18, pp.75-81.

VAZ, Filipe Costa; BRAGA, Cristina; TERESO, João Pedro; OLIVEIRA, Cláudia; GONZALEZ CARRETERO, Lara; DETRY, Cleia; MARCOS, Bruno; FONTES, Luís; MARTINS, Manuela (aceite) - Food for the dead, fuel for the pyre: symbolism and function of plant remains in provincial Roman cremation rituals in the necropolis of Bracara Augusta (NW Iberia). Quaternary Internacional.

VAZ, Filipe Costa; MARTÍN-SEIJO, María; CARNEIRO, Sérgio; TERESO, João Pedro (2016) - Waterlogged plant remains from the Roman healing spa of Aquae Flaviae (Chaves, Portugal): Utilitarian objects, timber, fruits and seeds. Quaternary International. Part A, pp. 86-103.

VAZ, Filipe Costa; SEABRA, Luís; TERESO, João Pedro; CARVALHO, Teresa Pires de (2017) - Combustível para um forno: dinâmicas de ocupação de um espaço em Monte Mozinho (Penafiel) a partir de novos dados arqueobotânicos. In ARNAUD, J. Morais; MARTINS, Andrea, eds. - Arqueologia em Portugal. 2017 - O Estado da questão. Lisboa: Associação dos Arqueólogos Portugueses, pp. 1331-1345. 


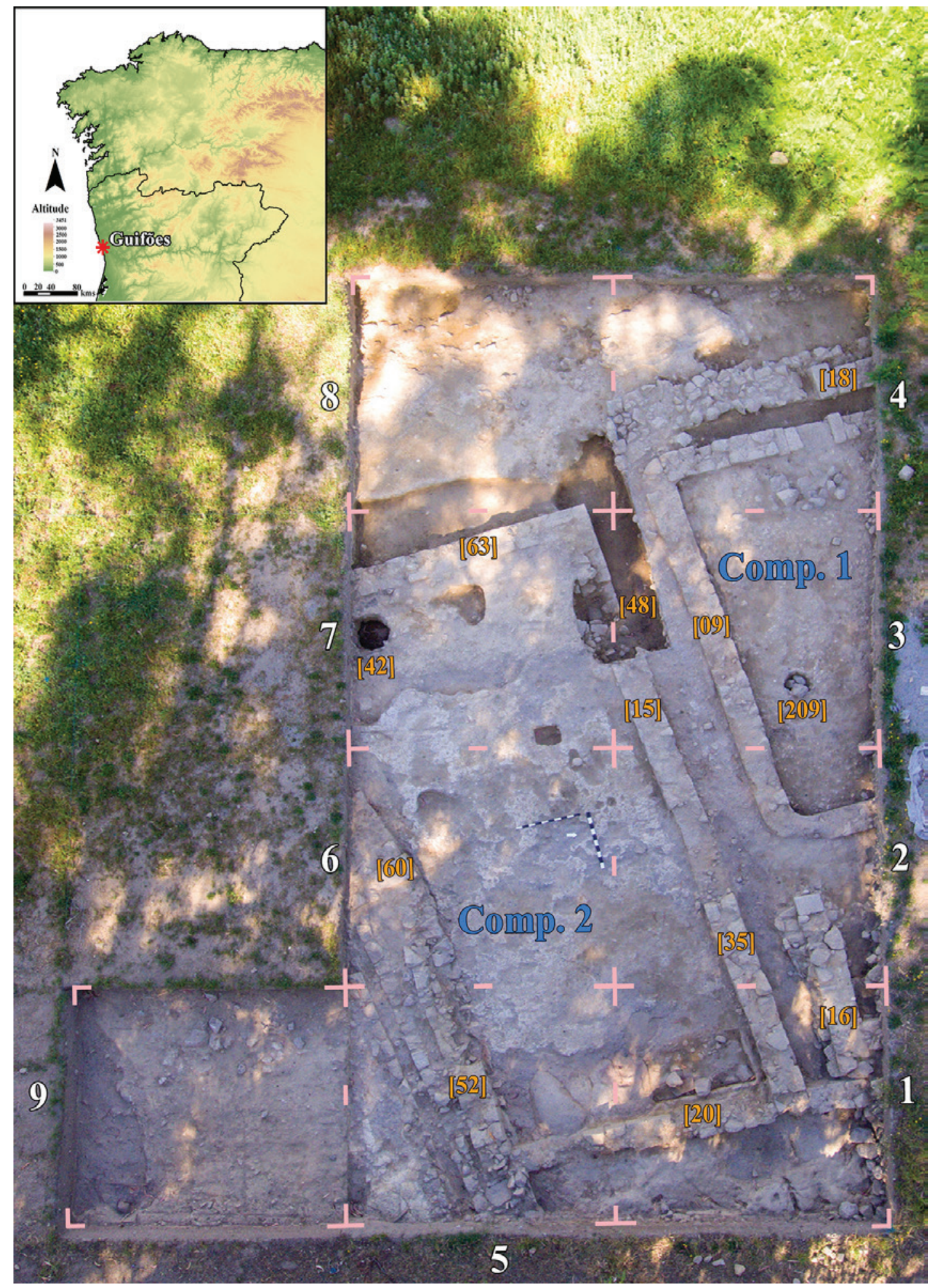

Figura 1 - Guifões no Noroeste Peninsular (parte superior esquerda) e vista aérea das intervenções no "Campo da Ponte” (campanha de 2019). Fotografia da autoria de César Guedes e adaptada de Arezes (2019). 


\begin{tabular}{|c|c|c|c|c|c|c|c|}
\hline Fase & U.E. & Quad. & $\begin{array}{c}\text { № } \\
\text { Amostras }\end{array}$ & Processamento & Volume & Contexto & Contexto Amostrado \\
\hline \multirow{5}{*}{$\begin{array}{l}\text { Idade } \\
\text { do Ferro }\end{array}$} & \multirow{2}{*}{65} & \multirow{2}{*}{1} & 1 & Flutuação & 14 & \multirow{2}{*}{$\begin{array}{l}\text { Junto a alinhamentos pétreos } \\
\text { [20] e [35] }\end{array}$} & \multirow{2}{*}{ Depósito disperso } \\
\hline & & & 5 & Manual & $\mathrm{N} / \mathrm{A}$ & & \\
\hline & \multirow{2}{*}{159} & \multirow{2}{*}{$5 / 6$} & 1 & Flutuação & 2 & \multirow{2}{*}{$\begin{array}{c}\text { Entre o alinhamento pétreo } \\
\text { [20] e o corte este }\end{array}$} & \multirow{2}{*}{ Depósito disperso } \\
\hline & & & 1 & Manual & $\mathrm{N} / \mathrm{A}$ & & \\
\hline & 163 & 5 & 1 & Manual & $\mathrm{N} / \mathrm{A}$ & $\begin{array}{l}\text { Delimitado por alinhamentos } \\
\text { pétreos [20] e [52] }\end{array}$ & Depósito disperso \\
\hline \multirow{8}{*}{$\begin{array}{l}\text { Período } \\
\text { Augustano }\end{array}$} & \multirow[b]{2}{*}{93} & \multirow[b]{2}{*}{$7 / 8$} & 2 & Flutuação & 16 & \multirow[b]{2}{*}{ Compartimento 2} & \multirow{2}{*}{$\begin{array}{c}\text { Enchimento da vala de } \\
\text { fundação do alinhamento } \\
\text { pétreo [63] }\end{array}$} \\
\hline & & & 7 & Manual & $\mathrm{N} / \mathrm{A}$ & & \\
\hline & \multirow[b]{2}{*}{43} & \multirow{2}{*}{$6 / 7$} & 2 & Flutuação & 26 & \multirow{2}{*}{$\begin{array}{l}\text { Compartimento 2. Junto a } \\
\text { alinhamento pétreo [6o] }\end{array}$} & \multirow{2}{*}{ Piso/Pavimento } \\
\hline & & & 4 & Manual & $\mathrm{N} / \mathrm{A}$ & & \\
\hline & 26 & $1 / 2$ & 4 & Flutuação & 18 & $\begin{array}{l}\text { Entre alinhamentos pétreos } \\
\text { [16] e [35] }\end{array}$ & Piso/Pavimento \\
\hline & 38 & 5 & 4 & Flutuação & 13 & $\begin{array}{c}\text { Junto a alinhamento pétreo } \\
{[52]}\end{array}$ & Depósito disperso \\
\hline & \multirow{2}{*}{47} & \multirow{2}{*}{$3 / 7$} & 2 & Flutuação & 11 & \multirow{2}{*}{$\begin{array}{l}\text { Interrupção alinhamento } \\
\text { pétreo [15] }\end{array}$} & \multirow{2}{*}{$\begin{array}{c}\text { Enchimento de } \\
\text { Interface/Vala [48] }\end{array}$} \\
\hline & & & 2 & Manual & $\mathrm{N} / \mathrm{A}$ & & \\
\hline $\begin{array}{l}\text { Final Id. } \\
\text { Ferro / Período } \\
\text { Romano } \\
\end{array}$ & 46 & 7 & 3 & Flutuação & 19,1 & Compartimento 2 & Enchimento da Fossa [42] \\
\hline \multirow{11}{*}{$\begin{array}{l}\text { Idade do } \\
\text { Ferro / Período } \\
\text { Romano }\end{array}$} & \multirow{2}{*}{56} & & 2 & Flutuação & 16,5 & $\begin{array}{l}\text { Compartimento 2. Delimitado } \\
\text { por alinhamentos pétreos }[20]\end{array}$ & Piso/Pavimento \\
\hline & & $1 / 2 / 5 / 6$ & 3 & Manual & $\mathrm{N} / \mathrm{A}$ & $\begin{array}{c}\text { por allnnamentos petreos [20] } \\
\text { e [35] }\end{array}$ & \\
\hline & 57 & 6 & 1 & Flutuação & 8 & Compartimento 2 & Depósito disperso \\
\hline & 57 & 0 & 1 & Manual & $\mathrm{N} / \mathrm{A}$ & & \\
\hline & 157 & $2 / 3$ & 1 & Flutuação & 11 & Entre alinhamento pétreo [og] & Depósito disperso \\
\hline & & & 2 & Manual & $\mathrm{N} / \mathrm{A}$ & e alinhamento pétreo [15] & \\
\hline & 188 & $3 / 4$ & 1 & Flutuação & 3 & $\begin{array}{c}\text { Retificação do } \\
\text { desmoronamento da vala [48] }\end{array}$ & Depósito disperso \\
\hline & 198 & $3 / 4$ & 2 & Flutuação & 16 & $\begin{array}{c}\text { Retificação do } \\
\text { desmoronamento da vala [48] }\end{array}$ & Depósito disperso \\
\hline & 36 & 1 & 3 & Flutuação & 12,1 & $\begin{array}{l}\text { Junto a corte este. Paralelo a } \\
\text { alinhamento pétreo [20] }\end{array}$ & Piso/Pavimento \\
\hline & & & 1 & Flutuação & 7 & Junto a corte norte e & Doń́citodianoro \\
\hline & 143 & 4 & 3 & Manual & $\mathrm{N} / \mathrm{A}$ & alinhamento pétreo [18] & Deposito disperso \\
\hline & 23 & 3 & 2 & Flutuação & 12 & Compartimento 1 & Lareira [32] \\
\hline & 11 & $2 / 4$ & 6 & Flutuação & 46,1 & Compartimento 1 & Denósito disnerso \\
\hline & 11 & $3 / 4$ & 6 & Manual & $\mathrm{N} / \mathrm{A}$ & Compartimento 1 & Deposito aisperso \\
\hline & 25 & $2 / 3$ & 4 & Flutuação & 46 & & \\
\hline & & & 3 & Manual & $\mathrm{N} / \mathrm{A}$ & Compartimento 1 & Deposito disperso \\
\hline & 184 & $1 / 3$ & 1 & Flutuação & 7 & Compartimento 1 & Depósito disperso \\
\hline Antiguidade & 41 & 7 & 4 & Flutuação & 6,2 & Compartimento 2 & $\begin{array}{c}\text { Enchimento da Fossa } \\
{[42]}\end{array}$ \\
\hline Tardia & 185 & 1 & 2 & Flutuação & 18 & $\begin{array}{l}\text { Compartimento 2. Delimitado } \\
\text { por alinhamentos pétreos [20] } \\
\text { e [35] }\end{array}$ & Depósito circunscrito \\
\hline & & ז/7 & 1 & Flutuação & 0,1 & Junto ao alinhamento pétreo & Denósito disnerce \\
\hline & 17 & $1 / 5$ & 2 & Manual & $\mathrm{N} / \mathrm{A}$ & {$[16]$} & Deposito disperso \\
\hline & 21 & 1 & 3 & Flutuação & 16,1 & $\begin{array}{c}\text { Junto ao alinhamento pétreo } \\
{[20]}\end{array}$ & Depósito disperso \\
\hline & 49 & 5 & 1 & Flutuação & 5 & $\begin{array}{l}\text { Entre alinhamento pétreo [20] } \\
\text { e corte este }\end{array}$ & \begin{tabular}{|c} 
Enchimento de Interface \\
{$[53]$}
\end{tabular} \\
\hline & 202 & 3 & 1 & Flutuação & 2 & Compartimento 1 & Lareira [209] \\
\hline $\begin{array}{l}\text { Romano / Ant. } \\
\text { Tardia }\end{array}$ & 51 & 8 & 1 & Flutuação & 6 & $\begin{array}{l}\text { Pequeno nível carbonizado } \\
\text { na parte central/centro-sul da } \\
\text { quadrícula } 8\end{array}$ & Depósito circunscrito \\
\hline $\begin{array}{l}\text { Id. Ferro / } \\
\text { Período }\end{array}$ & & & 4 & Flutuação & 26,5 & Compartimento 2. Junto a & \\
\hline $\begin{array}{c}\text { Romano / Ant. } \\
\text { Tardia }\end{array}$ & 176 & $1 / 2 / 5 / 6 / 7$ & 11 & Manual & $\mathrm{N} / \mathrm{A}$ & $\begin{array}{l}\text { alinhamentos pétreos }[52] \mathrm{e} \\
{[6 \mathrm{o}]}\end{array}$ & Depósito disperso \\
\hline
\end{tabular}

Tabela 1 - Inventário: Proveniência das amostras e contextualização das U.E. em análise. 


\begin{tabular}{|c|c|c|c|c|c|}
\hline \multirow{2}{*}{ № Amostra } & \multirow{2}{*}{$\begin{array}{c}\text { Malha } \\
\text { U.E. }\end{array}$} & \multicolumn{2}{|c|}{$1 \mathrm{~mm}$} & \multicolumn{2}{|c|}{$0,5 \mathrm{~mm}$} \\
\hline & & Peso inicial (g) & Triado (g) & Peso inicial (g) & Triado (g) \\
\hline 1 & 11 & 22,04 & 5,49 & 18,34 & 2,5 \\
\hline 2 & 11 & 7,86 & 7,86 & 13,36 & 1,64 \\
\hline 3 & 11 & 5,76 & 5,76 & 9,88 & 2,75 \\
\hline 4 & 21 & 10,96 & 4,81 & 10,37 & 2,46 \\
\hline 5 & 23 & 55,13 & 6,29 & 66,57 & 2,17 \\
\hline 6 & 23 & 20,98 & 5,18 & 24,32 & 1,79 \\
\hline 7 & 11 & 26,51 & 6,27 & 30,5 & 1,77 \\
\hline 8 & 21 & 14,62 & 7,89 & 12,44 & 1,63 \\
\hline 9 & 11 & 11,56 & 6,34 & 14,9 & 1,69 \\
\hline 37 & 49 & 57,98 & 9,71 & 47,65 & 2,43 \\
\hline 39 & 36 & 22,22 & 5,32 & 23,18 & 2,81 \\
\hline 49 & 65 & 35,96 & 6,77 & 50,62 & 3,18 \\
\hline 50 & 25 & 41,06 & 4,74 & 67,41 & 1,76 \\
\hline 51 & 185 & 11,28 & 4,81 & 32,58 & 3,78 \\
\hline 52 & 25 & 25,04 & 6,11 & 37,06 & 2,38 \\
\hline 53 & 57 & 14,03 & 7,15 & 23,45 & 2,82 \\
\hline 55 & 25 & 49,31 & 5,51 & 59,87 & 1,75 \\
\hline 59 & 43 & 5,09 & 5,09 & 15,68 & 1,97 \\
\hline 60 & 93 & 3,75 & 3,75 & 4,69 & 2,18 \\
\hline 61 & 157 & 8,02 & 8,02 & 17,07 & 2,06 \\
\hline 62 & 93 & 24,78 & 5,59 & 28,23 & 3,21 \\
\hline 63 & 185 & 13,09 & 5,56 & 25,55 & 3,3 \\
\hline 65 & 188 & 32,2 & 3,73 & 36,6 & 2,29 \\
\hline 66 & 176 & 6,98 & 6,98 & 9,41 & 2,25 \\
\hline 69 & 25 & 45,04 & 5,23 & 74,2 & 2,19 \\
\hline 70 & 56 & 7,34 & 7,34 & 15,53 & 2,08 \\
\hline 71 & 198 & 17,38 & 4,18 & 17,11 & 2,21 \\
\hline 72 & 198 & 20,51 & 5,06 & 20,07 & 2,18 \\
\hline 73 & 149 & 42,21 & 5,03 & 60,31 & 1,57 \\
\hline 74 & 143 & 7,09 & 7,09 & 16,24 & 2,1 \\
\hline 191 & 202 & 1,75 & 1,75 & 2,99 & 1,53 \\
\hline
\end{tabular}

Tabela 2 - Subamostragens realizadas. 


\begin{tabular}{|c|c|c|c|c|c|c|c|c|c|c|c|c|c|c|c|c|}
\hline \multirow{2}{*}{$\begin{array}{l}\text { Fase } \\
\text { U.E. } \\
\end{array}$} & \multicolumn{3}{|c|}{$\mathrm{F}$} & \multicolumn{5}{|c|}{ AUG } & \multicolumn{8}{|c|}{$\mathrm{F} / \mathrm{R}$} \\
\hline & 65 & 159 & 163 & 93 & 43 & 26 & 38 & 47 & 46 & 56 & 57 & 157 & 188 & 198 & 36 & 143 \\
\hline Volume (Litros) & 14 & 2 & $\mathrm{O}$ & 16 & 26 & 18 & 13 & 11 & 19,1 & 16,5 & 8 & 11 & 3 & 16 & 12,1 & 7 \\
\hline \multicolumn{17}{|l|}{ Cereais (grãos) } \\
\hline Hordeum vulgare & & & & & 1 & & & & & 1 & & & & & & \\
\hline Panicum miliaceum & 6 & & & 5 & 2 & 10 & 7 & & 17 & 1 & 1 & 2 & & 5 & 3 & 2 \\
\hline Setariaitalica & 1 & & & 1 & 3 & & & 1 & 3 & & & & & & & \\
\hline Panicum/Setaria & & & & 1 & 1 & 2 & & & 6 & & & & 1 & 1 & 4 & 1 \\
\hline \multicolumn{17}{|l|}{ Secale cereale } \\
\hline Triticum aestivum/durum & & & & 4 & & 4 & & & 12 & & & & & 4 & 5 & \\
\hline Triticum sp. & 1 & & & 1 & & & & & & & & & & 2 & & 1 \\
\hline Triticeae & 1 & & & & 1 & & 1 & & 4 & & & & & 2 & & \\
\hline \multicolumn{17}{|l|}{ Cereais (inflorescências) } \\
\hline Hordeum vulgare (base lema) & & & & & & & 1 & & 1 & & & & & & & \\
\hline Secale cereale (segmento de ráquis c/ 1 nó) & & & & & & 1 & & & & & & & & & & \\
\hline Secale cereale (ráquis frag.) & & & & & & & & & 1 & & & & & & & \\
\hline Triticum aestivum/durum (nó ráquis) & & 1 & & 4 & & 15 & 2 & & 11 & & & 2 & & 2 & 1 & \\
\hline \multicolumn{17}{|l|}{ Fabaceae } \\
\hline Ornithopus sp. (semente) & & & & & & & & & 1 & & & 1 & & & & \\
\hline Ornithopus sp. (síliqua) & & & & & & 1 & & & & & & & & 2 & & \\
\hline Vicia faba (semente) & & & & & & & & & 1 & & & & & 1 & 1 & \\
\hline Vicia/Lathyrus (semente) & & & 1 & & & 2 & & & & & & 1 & & & & \\
\hline Fabaceae tipo Genista (semente) & & & & & & & & & 1 & & & & & 2 & & \\
\hline Fabaceae (semente) & & & & 2 & 1 & & & & & 2 & & & & 1 & & \\
\hline \multicolumn{17}{|l|}{ Outras Poaceae (grãos) } \\
\hline Avena sp. & & 1 & & 1 & 3 & 1 & & 1 & 4 & & & & & 2 & & \\
\hline Festuca/Lolium & & & & & & 1 & & & & & & & & & & \\
\hline Poa sp. & & 1 & & & 1 & & & & & & & & & & & \\
\hline Setaria sp. & & & & & 1 & & & & & & & & & & & \\
\hline Panicoideae & & 2 & & 1 & & 1 & & 1 & & & & & & 1 & 1 & \\
\hline Poaceae & 1 & & & & 1 & 1 & & & 1 & & & 2 & & & & \\
\hline \multicolumn{17}{|l|}{ Poaceae (espigueta c/grão) } \\
\hline Frutos & & & & & & & & & & & & & & & & \\
\hline Castanea sativa (fruto frag.) & & & & & & & & & & & & & & & & \\
\hline Prunus persica (caroço frag.) & & & & & & & & & 1 & & & & & & & \\
\hline Quercus sp. (cotilédone frag.) & & & & & & & & & & & & & & & & \\
\hline Rubus sp. (aquénio) & & & & & 1 & & & & 1 & & & & & & & \\
\hline Outros & & & & & & & & & & & & & & & & \\
\hline Anagallis arvensis (semente) & & & & & & & & & & & & & 1 & & & \\
\hline Asteraceae tipo Chrysanthemum (aquénio) & & & & 1 & & 2 & 1 & 1 & & & & & & & & \\
\hline Asteraceae (aquénio) & & & & 1 & & & & & 3 & & & & & & & \\
\hline Caryophyllaceae (semente) & & & & & & 1 & 2 & & 2 & & & & & & & \\
\hline Corema album (semente) & 8 & 1 & & 2 & & 2 & & 1 & 3 & & & & & 1 & & 1 \\
\hline Galium sp. (mericarpo frag.) & 1 & & & & & & & & & & & & & & & \\
\hline Malva sp. (semente) & & & & & & & & & & & & & & & & \\
\hline Plantago sp. (semente) & & & & & 1 & & & & & & & & & & & \\
\hline Polygonum lapathifolium (aquénio) & & & & & & 1 & & & & & & & & & & \\
\hline Polygonum sp. (aquénio) & & & & & & & & & & & 1 & & & & & \\
\hline Polygonaceae (aquénio) & & & & & & & & & & & & & & & & \\
\hline Portulaca oleracea (semente) & & & & & & & & & 1 & & & & & & & \\
\hline Raphanus raphanistrum (síliqua) & & & & & & 1 & & & 1 & & & & & & & \\
\hline Rumex bucephalophorus (aquénio) & & & & & & & & & & & & & & & & \\
\hline Rumex sp. (aquénio) & & & & & & & & & & & & & & & & \\
\hline Sambucus sp. (caroço) & & & & & & & & & 1 & & & & & & & \\
\hline Solanaceae (semente) & & & & & & & & & 1 & & & & & & & \\
\hline Spergula arvensis (semente) & & & & & & & & & & & & & & & & \\
\hline Urtica sp. (aquénio) & & & & & & & & & & & & & & & & \\
\hline Verbena officinalis (mericarpo) & & & & & 1 & & & & & & & & & & & \\
\hline Viola sp. (semente) & & & & & & & & & & & & & & & & \\
\hline Indeterminado unidade & 2 & & & 1 & 1 & 1 & 1 & & 1 & & & & & & 2 & \\
\hline Total & 21 & 6 & $\mathbf{I}$ & 25 & 19 & 47 & 15 & 5 & 78 & 4 & 2 & 8 & 2 & 26 & 17 & 5 \\
\hline
\end{tabular}

Tabela 3 - Resultado do estudo carpológico. Legenda: F - Ferro; AUG - Período de Augusto; R - Período Romano; AT Antiguidade Tardia. 


\begin{tabular}{|c|c|c|c|c|c|c|c|c|c|c|c|c|}
\hline \multirow{2}{*}{$\begin{array}{c}\text { Fase } \\
\text { U.E. } \\
\end{array}$} & \multicolumn{9}{|c|}{ AT } & \multicolumn{2}{|c|}{$\mathrm{R} / \mathrm{AT}$} & \multirow{2}{*}{$\frac{\mathrm{F} / \mathrm{R} / \mathrm{AT}}{176}$} \\
\hline & 23 & 11 & 25 & 184 & 41 & 185 & 17 & 21 & 49 & 202 & 51 & \\
\hline Volume (Litros) & 12 & 46,1 & 46 & 7 & 6,2 & 18 & 0,1 & 16,1 & 5 & 2 & 6 & 26,5 \\
\hline \multicolumn{13}{|l|}{ Cereais (grãos) } \\
\hline Hordeum vulgare & 1 & 1 & 1 & & & & & 1 & & & & 1 \\
\hline Panicum miliaceum & 30 & 36 & 11 & & 1 & 2 & & 5 & 1 & & & 12 \\
\hline Setaria italica & 3 & & 3 & & 2 & & & & & 1 & & 1 \\
\hline Panicum/Setaria & 8 & 11 & 3 & & 6 & & & 3 & & 1 & & 3 \\
\hline Secale cereale & 4 & 1 & 14 & & & 3 & & 5 & 1 & & & \\
\hline Triticum aestivum/durum & & 1 & 8 & & & & & 5 & & & & 8 \\
\hline Triticum sp. & & & & & & 1 & & & & & & 1 \\
\hline Triticeae & 1 & 1 & & & & & & 4 & 2 & & & 1 \\
\hline \multicolumn{13}{|l|}{ Cereais (inflorescências) } \\
\hline \multicolumn{13}{|l|}{ Hordeum vulgare (base lema) } \\
\hline Secale cereale (segmento de ráquis c/ 1 nó) & 8 & 1 & 5 & & & & & & & & & \\
\hline Secale cereale (ráquis frag.) & 4 & & & & & & & & & & & \\
\hline Triticum aestivum/durum (nó ráquis) & & & & & 1 & 1 & & 9 & & & & 11 \\
\hline \multicolumn{13}{|l|}{ Fabaceae } \\
\hline Ornithopus sp. (semente) & 1 & & & & & 1 & 1 & & & & & 1 \\
\hline Ornithopus sp. (síliqua) & & & & & 1 & & & & & & & 1 \\
\hline Vicia faba (semente) & & & 2 & & & & & & & & & \\
\hline Vicia/Lathyrus (semente) & 2 & & & & & & & & & & & 1 \\
\hline Fabaceae tipo Genista (semente) & & & & & & & & & & & 1 & \\
\hline Fabaceae (semente) & 5 & & 2 & & & 2 & & 1 & & & & 1 \\
\hline \multicolumn{13}{|l|}{ Outras Poaceae (grãos) } \\
\hline Avena sp. & & & 1 & & & & & 2 & & & & 1 \\
\hline \multicolumn{13}{|l|}{ Festuca/Lolium } \\
\hline Poa sp. & & & 1 & & & & & & & & & \\
\hline Setaria sp. & & & 2 & & & & & & & & & \\
\hline Panicoideae & 1 & 1 & 2 & 1 & & 1 & & 1 & & 2 & & 2 \\
\hline Poaceae & 3 & & 3 & & & & & 1 & & & & 1 \\
\hline Poaceae (espigueta c/grão) & & 1 & & & & & & & & & & \\
\hline \multicolumn{13}{|l|}{ Frutos } \\
\hline Castanea sativa (fruto frag.) & & 11 & & & & & & & & & & \\
\hline Prunus persica (caroço frag.) & & & 1 & & & & & & & & & \\
\hline Quercus sp. (cotilédone frag.) & & & 1 & & & & & & & & & \\
\hline \multicolumn{13}{|l|}{ Rubus sp. (aquénio) } \\
\hline Outros & & & & & & & & & & & & \\
\hline Anagallis arvensis (semente) & & & & & & & & & & & & \\
\hline Asteraceae tipo Chrysanthemum (aquénio) & 1 & & & & & & & 1 & & & & 1 \\
\hline Asteraceae (aquénio) & & & & & & & & & & & & 3 \\
\hline Caryophyllaceae (semente) & & & & & & & & & & & & \\
\hline Corema album (semente) & & 1 & & & & & 1 & 6 & & & & 1 \\
\hline Galium sp. (mericarpo frag.) & & & & & & & & & & & & \\
\hline Malva sp. (semente) & & & & & 1 & & & & & & & 1 \\
\hline Plantago sp. (semente) & & & & & & & & & & & & \\
\hline Polygonum lapathifolium (aquénio) & & & & & & & & & & 1 & & \\
\hline Polygonum sp. (aquénio) & & & & & & & & & & & & \\
\hline Polygonaceae (aquénio) & & & & & & & & 1 & & & & \\
\hline Portulaca oleracea (semente) & & & & & & & & & & & & \\
\hline Raphanus raphanistrum (síliqua) & & 1 & & & & & & & & & & \\
\hline Rumex bucephalophorus (aquénio) & & & & & & & & 1 & & & & \\
\hline Rumexsp. (aquénio) & & 1 & & & & & & & & & & 1 \\
\hline Sambucus sp. (caroço) & & & & & & & & & & & & \\
\hline Solanaceae (semente) & & & & & & & & & & & & \\
\hline Spergula arvensis (semente) & 1 & & & & & & & & & & & \\
\hline Urtica sp. (aquénio) & & 1 & & & & & & & & & & \\
\hline Verbena officinalis (mericarpo) & & & & & & & & & & & & \\
\hline Viola sp. (semente) & & & & & & & & 1 & & & & \\
\hline Indeterminado unidade & & & 1 & 1 & & & & 4 & & & & \\
\hline Total & 73 & 69 & 61 & 2 & 12 & 11 & 2 & 51 & 4 & 5 & 1 & 53 \\
\hline
\end{tabular}

Tabela 3 (continuação) - Resultado do estudo carpológico. Legenda: F - Ferro; AUG - Período de Augusto; R - Período Romano; AT - Antiguidade Tardia. 



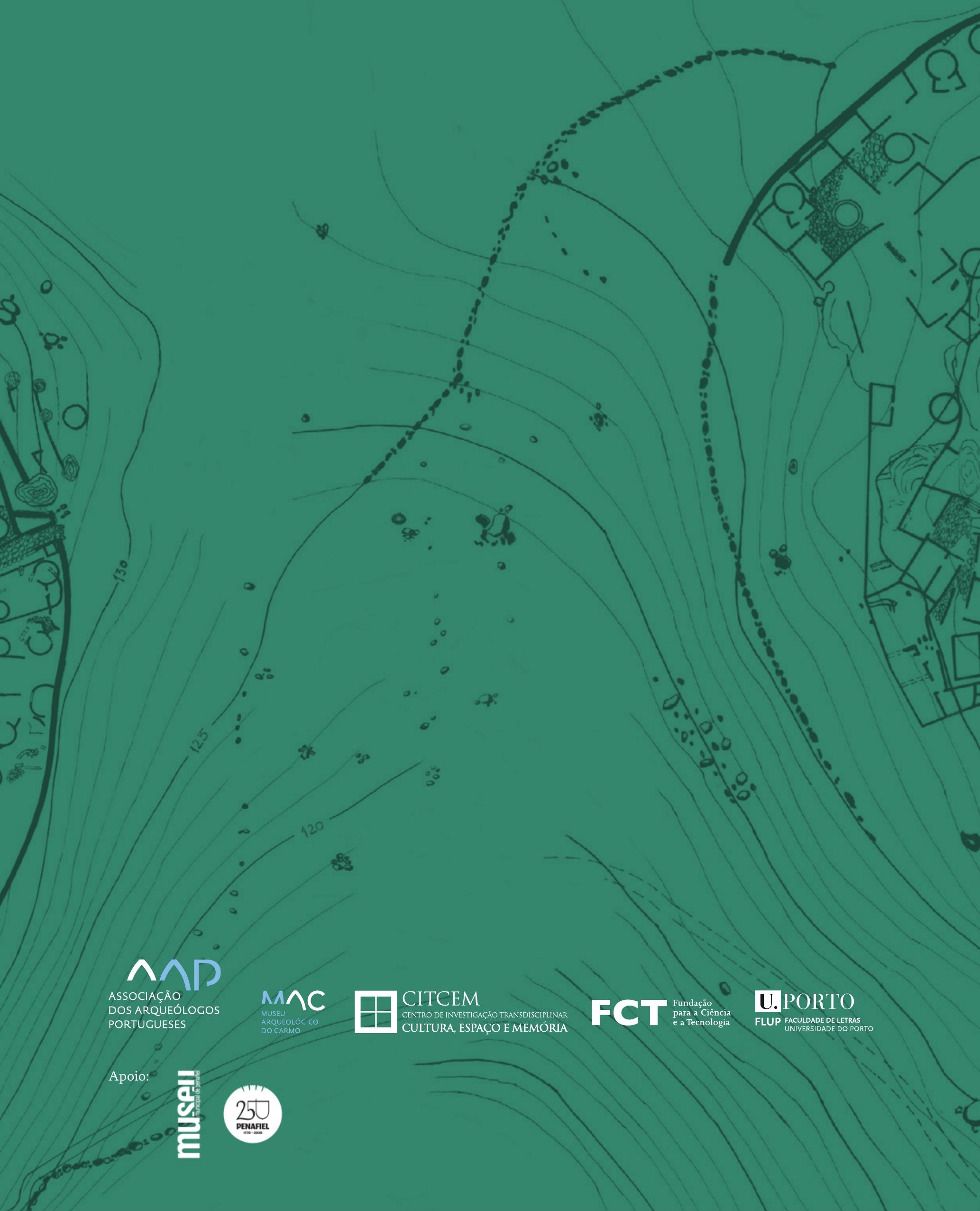

